\title{
El romance del occidente de Vizcaya en su toponimia. Bosquejo histórico
}

En el caso vasco-románico, la contribución de la toponimia a la solución de problemas de naturaleza histórica parece especialmente apreciada, en particular por lo que se refiere a la cuestión siempre debatida de la extensión e intensidad de la romanización, y del carácter residual o importado del vasquismo de algunas comarcas en la época medieval y moderna ${ }^{1}$. Estos problemas se plantean sobre todo para Álava, zonas de Navarra y el occidente de Vizcaya. De este último espacio, el comprendido entre el Nervión y Bilbao, Burgos y Cantabria, el territorio que abarca la comarca vizcaína conocida como Encartaciones, hablan estas páginas.

La filología española ha permitido un inexplicable vacío sobre el romance en el territorio político correspondiente a la lengua vasca, como ha expresado María Teresa Echenique en varios conocidos trabajos ${ }^{2}$, en los que defiende el carácter autóctono del romance entre vizcaínos y guipuzcoanos, derivado directamente del latín y no importado de áreas vecinas ${ }^{3}$. Pues bien, al emprender la exploración del romance en Vizcaya a partir de su toponimia, se advierte claramente que éste dista de mostrarse uniforme. El globalmente aludido romance vizcaíno y guipuzcoano, "tan peculiar", en palabras de la profesora Echenique ${ }^{4}$, se desarrolla en

1 Así lo señala L. MichelenA, "Nota marginal sobre la huella latina en la lengua vasca", Fontes Linguae Vasconum, III (1972), pp. 12-13.

2 Cf., entre otras páginas de M. T. ECHENIQUE, "El romance en territorio euskaldún", en R. CIÉRBIDE (dir.), Lengua y literatura románica en torno al Pirineo (Bilbao: Universidad del País Vasco, 1986), p. 159, y "La lengua vasca y el mundo románico", Letras de Deusto, XL (1988), p. 233.

3 "Que el riojano forma comunidad con navarro y aragonés parece claro y, además, implica comunidad de origen; pero ello no implica, desde luego, que inicialmente no existieran diferencias más o menos acusadas entre sí. Que el castellano de Álava comparta caraterísticas de la variedad burgalesa, es también obvio. Pero las peculiaridades del romance hablado en las provincias actuales de Guipúzcoa y Vizcaya (mal estudiadas, en general) y que se registran incluso en individuos que no hablan euskera, esto es, no pueden ser achacadas a interferencias lingüísticas vasco-románicas en un individuo, sino en una comunidad, quizá nos estén mostrando el perfil del romance autóctono" (M. T. ECHENIQUE, Historia lingüística vasco-románica. Intento de aproximación [San Sebastián: Caja de Ahorros Provincial de Guipúzcoa, 1984], p. 63).

4 "El romance...*, cit., p. 154. 

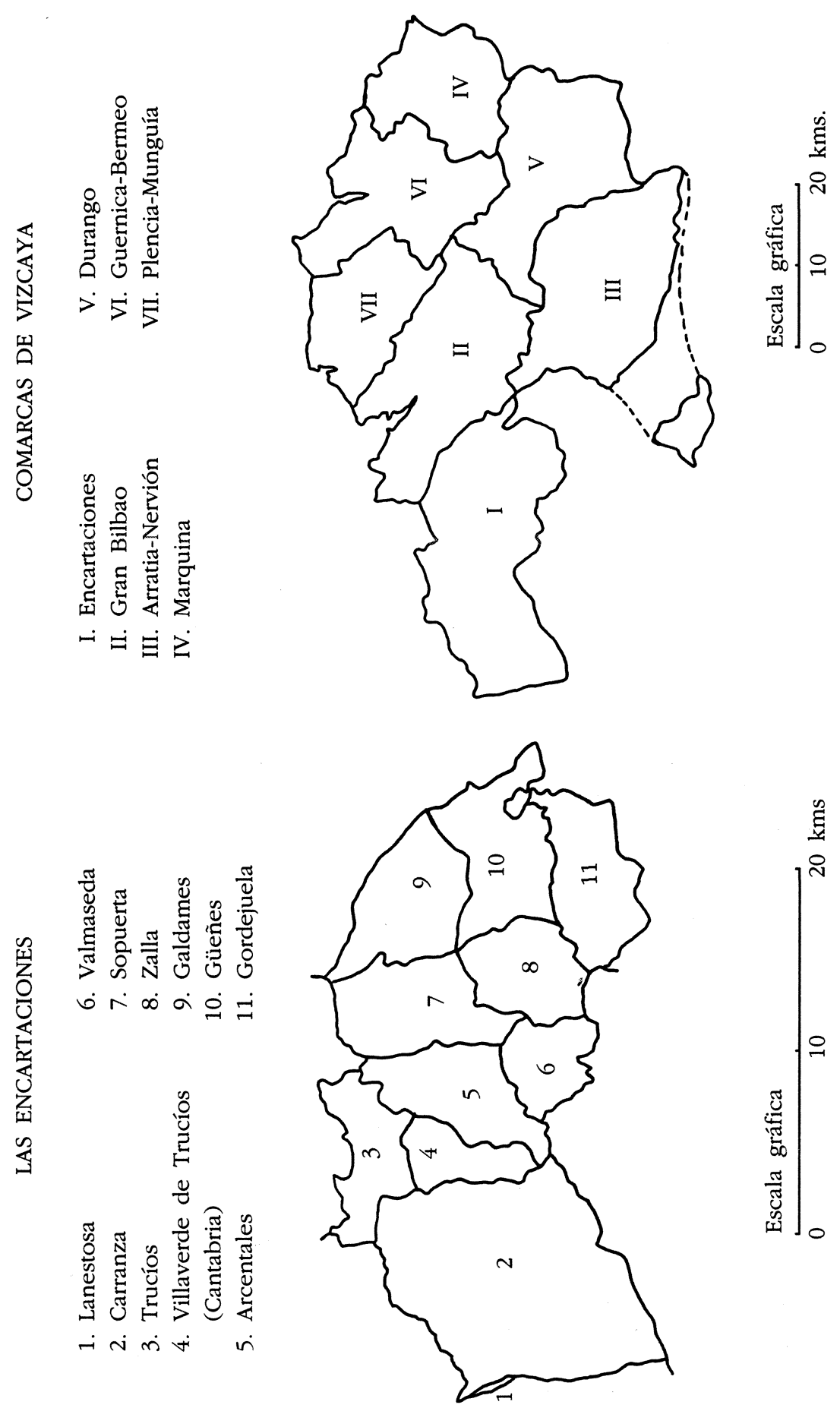
territorio de lengua vasca hasta la actualidad, mientras que el romance del occidente de Vizcaya, el de Las Encartaciones, que no manifiesta huellas de bilingüismo vasco latino o vasco-románico, tiene comunidad de rasgos $\mathrm{y}$ origen con las comarcas vecinas cántabras y burgalesas.

\section{VASCUENCE Y ROMANCE EN LAS ENCARTACIONES}

Se sabe con certeza que en Las Encartaciones no se ha hablado vascuence, excepto por los nuevos euskaldunes y gentes procedentes de otros puntos de Vasconia, ni en este siglo ni en el pasado ${ }^{5}$. Pero suele suponerse que la comarca corresponde al territorio histórico de la lengua vasca, pues es corriente sobreentender que los contornos políticos y administrativos provinciales aseguran una homogeneidad étnica y lingüística, esencial y constitutiva de toda su demarcación. Por ello, la primitiva vasconidad perdida de Las Encartaciones suele respetarse casi como axioma ${ }^{6}$.

5 En 1802, el autor del artículo "Vizcaya" del Diccionario geográfico-bistórico de España, de la Real Academia de la Historia, indica que «en Las Encartaciones y villas de Portugalete, Valmaseda y Lanestosa, sólo se usa el castellano; bien que los nombres de muchos de sus pueblos son vascongados, y dan a entender haberse usado allí también en algún tiempo aquel idioman. Tomamos esta cita de CARO BAROJA, Materiales para una bistoria de la lengua vasca en su relación con la latina (Salamanca: Acta Salmanticensia, I, 1946), p. 18, quien reproduce asimismo la siguiente indicación de ITURRIZA, Historia General de Vizcaya y Epítome de las Encartaciones (Bilbao: Diputación de Vizcaya, 1967) (ed. original de 1812), vol. II, 302: “En las Encartaciones no es bulgar el bascuence sino el romance, o castellano; y algunos se persuaden que perdieron la frecuer sia de aquél en tiempo que estubieron sujetas a los Reyes de Asturias y León [...].

6 Examínense si no las siguientes declaraciones sorprendentes: "Faltos de conocer su nombre euskérico primitivo, nos hemos de contentar, pues, con el latino Incartationes que, a nuestro conocimiento, sólo aflora en la documentación de la segunda mitad del siglo XII" (Enciclopedia General Ilustrada del País Vasco [San Sebastián: Auñamendi, 1967-], s.v. Encartaciones; la cursiva es nuestra); hemos subrayado la presuposición inicial, que carece de todo fundamento. En el mismo artículo se dice que la lengua de la comarca es hoy el castellano, pero que "en otros tiempos sus habitantes se expresaban en euskera", con otras aseveraciones de la misma índole. No parece haber más datos para apoyar estas afirmaciones que los supuestos que algunos escritores de los siglos XVIII y XIX (Trueba, Escarzaga, Labayru) alegaron como restos de un posible hundimiento de la lengua vasca en la zona. A título de ejemplo reproducimos un pequeño texto del costumbrista encartado Trueba (Las Encartaciones, recopilación de escritos [Bilbao: Geu, 1978], p. 63), quien se expresaba así: "En vez de citar Iturriza [autor de la Historia General de Vizcaya y Epitome de las Encartaciones, 1812] algunos nombres de localidades pertenecientes a la lengua eúskara, debiera haber dicho que todos los nombres antiguos pertenecían a esta lengua en las Encartaciones, y los 


\subsection{Vizcaya indoeuropea}

Sin embargo, es hoy opinión común entre los historiadores que, en la Antigüedad, Las Encartaciones vizcaínas formaron parte de la Hispania indoeuropea, y los pocos datos toponímicos contemplados en la indagación de los límites occidentales de la lengua vasca no permiten sostener otra cosa: "...se pasa de una toponimia íntegramente vasca, a una toponimia como la de la orilla izquierda de la ría [del Nervión], donde algunos restos vascos son restos sumergidos de antiguo en otro ambiente lingüísticon, afirmaba ya Tovar ${ }^{7}$. En la época en que la Península entra en la órbita romana, Las Encartaciones forman parte del territorio que se considera propio de los autrigones, mientras que el resto de Vizcaya y parte de Guipúzcoa y Álava estaba ocupado por otras tribus genéricamente denominadas caristias ${ }^{8}$. Aunque no sea tarea fácil describir con precisión los límites de los pueblos prerromanos, en todo caso, se acepta que fue el

que pertenecen a la castellana es por ser relativamente modernos y aun por haberse traducido o castellanizado no pocos de los antiguos, de lo que da testimonio su sintaxis que conserva la eúskara por mala traducción, como sucede, por ejemplo, con el nombre de Montellano en Galdames, que corresponde, designado en vascuence por Mendi-celaya, y con el del Regato en Barakaldo, que siendo Mendi-erreca o Riachuelo del monte, se le tradujo por Monte-Regato como Lope García de Salazar le llamaba en 1470 .

7 El euskera y sus parientes (Madrid: Minotauro, 1959), p. 169. Michelena se muestra de acuerdo con Tovar en que la toponimia indica que el límite de la lengua vasca, que aparece cortado de una manera mucho más clara al oeste que al este, sugiere que, si dialectos de tipo vasco se hablaron más allá de la frontera histórica occidental del vasco en Vizcaya, fueron suplantados en fecha muy remota por dialectos indoeuropeos. Contrariamente, por el este la transición es gradual y los nombres de lugar de tipo vascoide se siguen extendiendo hacia oriente, con densidad variable, a lo largo del Pirineo; cf. L. Michelena, Sobre el pasado de la lengua vasca (San Sebastián: Auñamendi, 1964), p. 86.

8 En 1929, Sánchez Albornoz, por medio de un análisis riguroso de las inscripciones, del relato de los geógrafos clásicos y de los hallazgos arqueológicos, amén de ciertas señales lingüísticas toponímicas, propuso unos límites, en general aceptados, según los cuales, "Autrigonia habría ocupado un territorio integrado por la Bureba al Sur, las tierras de Villarcayo y de Medina de Pomar en el Centro y Las Encartaciones en el Norte" (C. SÁNCHEZ AlBORNOZ, "Divisiones tribales y administrativas del solar del reino de Asturias en la época romana", Boletin de la Real Academia de la Historia, XCV [1929], p. 364). De esa división se hacen eco, entre otros, CARO BAROJA, Los pueblos del Norte de la Peninsula Ibérica (análisis histórico-cultural) (San Sebastián: Txertoa, 1973) (2." ed.), p. 42, y J. M. SOlANa SáINZ, Autrigonia romana, zona de contacto Castilla-Vasconia (Valladolid: Universidad de Valladolid, 1979), p. 33. 
Nervión, hasta su desembocadura (coincidiendo con el arranque en este punto de Las Encartaciones), el límite oriental de Autrigonia, en la llamada Hispania indoeuropea, de la que, desde los comienzos de la Edad del Hierro, podemos hablar con cierto fundamento, frente a una Hispania no indoeuropea ${ }^{9}$. Constatar que el occidente vizcaíno corresponde, a la llegada de los romanos, a la parte ya indoeuropeizada de la Península, puede ser un dato fundamental para trazar la historia lingüística de la comarca y, más aún, en la investigación de su toponimia, para la que el criterio del área geográfica de las diferentes lenguas es básico: "No deben buscarse nombres mapuches donde no hubo Aucaes ni cacanes adonde no llegaron los Diaguitas, ni es razonable esperar muchos nombres quichuas lejos de las zonas peruanizadas y de los caminos del Incan, dicho sea con el expresivo ejemplo de Corominas ${ }^{10}$.

9 Siempre habrá que tener presente la escasez de datos escritos o arqueológicos de que disponemos y las modificaciones posibles de esos límites en la época imperial romana; cf. C. GARCía MERINo, Población y poblamiento en Hispania romana. El Conventus Cluniensis (Valladolid: Universidad de Valladolid, 1975), p. 14. También debemos asumir que al abordar el intrincado problema de las migraciones indoeuropeas, en principio, no parece correcto trazar líneas absolutas que encuadren la repartición de unos pueblos u otros, pues éste es más bien un problema de intensidad o densidad, como advierte Caro Baroja; cf. J. CARo BArojA, Materiales..., cit., p. 200; Los pueblos de España (Madrid: Istmo, 1981), vol. I, p. 175. Desde la lingüística se ha hecho hincapié en la complejidad de las invasiones indoeuropeas que, en la Península, se sucedieron a lo largo del último milenio a. C., por ejemplo, Tovar en sucesivos trabajos: así en "Las invasiones indoeuropeas, problema estratigráfico", Zephyrus, VIII (1957), pp. 81-82; Lenguas y pueblos de la Antigua Hispania: lo que sabemos de nuestros antepasados protobistóricos (Vitoria: Universidad del País Vasco, 1985), p. 19. Dentro del complejo panorama de las migraciones indoeuropeas en la Península, concretar la filiación étnica y lingüística de los autrigones no parece empresa fácil, aunque se ha sostenido su carácter céltico; cf. J. M. Solana SÁINZ, op. cit., pp. 54-55, quien señala lo siguiente: "...podemos afirmar que el valle del Nervión y las Encartaciones vizcaínas, desde épocas remotas ¿s.VII?, estuvieron ocupadas por gentes celtas del grupo de belgae, al menos los escasos datos de que disponemos así lo ponen de manifiesto. Que en época anterior existieran gentes autóctonas, que vivían en la Edad de Bronce y que eran descendientes muy lejanos de los antiguos ocupantes de las cuevas paleolíticas, esto es otro cantar. Lo que sí podemos afirmar es que enseguida fueron asimilados por los nuevos pueblos más adelantados culturalmente".

10 J. COROMinas, Tópica Hespérica. Estudios sobre los antiguos dialectos, el substrato y la toponimia romances (Madrid: Gredos, 1972), vol. I, pp. 130-131. La filología española se ha servido, a veces, del argumento de la continuidad entre los límites tribales entre pueblos prerromanos (cántabros, astures, galaicos) y algunas isoglosas de gran importancia en la fragmentación dialectal peninsular. A la inversa, Sánchez Albornoz utiliza en 1929 (op. cit.) el conocimiento adquirido sobre límites dialectales romances, para confirmar las divisiones tribales de la Antigüedad, recalcando el valor de ríos 


\subsection{Toponimia prerromana}

La investigación pormenorizada de la toponimia de Carranza, el más occidental de los valles de Las Encartaciones ${ }^{11}$, nos ha conducido a construir con materiales escritos y orales un corpus exhaustivo de formas léxicas y toponímicas, que nos permite ahora hablar con fundamento de las características históricas de la lengua de la comarca. De la prehistoria lingüística, a la que estamos aludiendo, el topónimo Carranza (río y valle) es muestra ejemplar, como nombre de raigambre preindoeuropea, que sin embargo plantea cierta dicotomía con el tipo de nombres preindoeuropeos que se encuentran al este de la línea del Nervión, en el territorio histórico de la lengua vasca. Encontramos formas afines en la Hispania indoeuropea cantábrica, como el asturiano Santa Eulalia de Carranzo ${ }^{12}$, o el montañés Carranceja, además de los alaveses La Carranza en Bernedo (a. 1654) y Carranceta en Ayala. La bibliografía sobre el léxico

como el Navia, el Sella, el Nervión y el Deva. Sin embargo, en este terreno es bastante corriente incurrir en petición de principio, pues se apela a los límites dialectales contemporáneos para probar la existencia de unas supuestas demarcaciones tribales que, a su vez, sin ser bien conocidas, han sido evocadas para explicar esos límites dialectales contemporáneos.

11 Carranza, con sus más de $137 \mathrm{~km}^{2}$, es un extenso valle en el límite de Vizcaya con Cantabria y Burgos; en un paisaje montuoso y quebrado, su población, muy dispersa, tiene en la ganadería la principal fuente de riqueza. Los otros municipios históricos que componen Las Encartaciones son Tres Concejos del Valle de Somorrostro (Santurce, Sestao, San Salvador del Valle), Cuatro Concejos del Valle de Somorrostro (Musques, Ciérvana, Abanto de Suso y Abanto de Yuso), Güeñes, Zalla, Galdames, Sopuerta, Arcentales, Trucíos y las villas de Portugalete, Valmaseda y Lanestosa. A ellos debe sumarse el enclave cántabro de Villaverde de Trucíos.

12 P. MADOZ, Diccionario geográfico-estadístico-histórico de España y sus posesiones de Ultramar (Madrid: Estudio Literario-Tipográfico de P. Madoz y L. Sagasti, 18451850); a partir de ahora, cuando citemos un topónimo español sin señalar otra fuente, debe entenderse que se trata del diccionario de Madoz. Asimismo, para evitar la reiteración de algunas referencias bibliográficas, señalamos ahora que los datos toponímicos alaveses proceden, principalmente de G. LÓPEZ DE GUEREÑU, Toponimia alavesa (Bilbao: Euskaltzaindia, 1989); y de F. DE BARRENENGOA, Onomástica de la Tierra de Ayala (Vitoria: Diputación de Álava, 1988-1990) (3 vols.). Además, hemos encontrado la mayoría de los topónimos montañeses que citaremos en la Gran Enciclopedia de Cantabria (Santander: Cantabria S. A., 1985) (8 vols.); y en las siguientes obras de F. Sojo y LomBA: "De Re Toponímica. Comunicaciones en Cantabria", Boletín de la Real Sociedad Geográfica, LXXXIII (1947), pp. 7-71; "De Re Toponímica", Boletín de la Real Sociedad Geográfica, LXXXVI (1950), pp. 199-230; "Paseo toponímico por Cantabria», Boletín de la Real Sociedad Geográfica, LXXXVII (1951), pp. 569-607. 
y la toponimia derivados de la raíz CARR-, considerada unánimemente de ascendencia preindoeuropea, es copiosísima ${ }^{13}$. En cuanto al elemento sufijal $-n z$-, reaparece en otros topónimos del Valle: Matienzo, Pedranzo, Toranzo $\mathrm{y}$, seguramente, Ordunte. Se encuentra asimismo en los varios Arganza de Asturias y Castilla, y en un Argança portugués, del distrito de Porto. Documentado preferentemente en hidrónimos, el formante -NT- correspondería a una capa lingüística indoeuropea no diferenciada, precéltica ${ }^{14}$.

13 A. Nouvel estima que el significado original o denominador común de todos los miembros de esta familia, es la noción fundamental de 'dureza', de donde las de 'sequedad' e incluso 'esterilidad' ("Le pré-indoeuropéen KAR-/ GAR- 'pierre' et KAR/ GAR- 'plante, arbre' ont-ils une origine commune?", Mélanges de Philologie Romane offerts à Charles Camproux [Montpellier: Universidad P. Valéry-Centro de Estudios Occitanos, 1978], vol. II, pp. 967-970). F. Krüger ha relacionado con esta raíz varios cientos de voces iberorromances (cf. Problemas etimológicos. Las raíces CARR-, CORRen los dialectos peninsulares [Madrid: CSIC, 1956]). Merecen consultarse, además, los siguientes estudios: T. BUESA, "La raíz preindoeuropea *KAL- en algunos topónimos alto aragoneses", Actas del $V$ Congreso Internacional de Ciencias Onomásticas (Salamanca: Acta Salmanticensia, XI, 1958), pp. 137-171; A. DAUZAT, La toponymie française (Paris: Payot, 1971), pp. 81-102; Ch. BAYLON y P. FABRE, Les noms de lieux et de personnes (Paris: Nathan, 1982), pp. 65-67. Es fundamental el trabajo de KRAHE Spracb verwandtschaft im alten Europa (Heidelberg, 1951), sobre cuyas hipótesis puede verse el artículo de J. J. HOZ BRAvo, "Hidronimia antigua europea en la Península Ibérican, Emerita, XXXI (1963), pp. 227-242; cf. también G. ALESsio, "La base preindoeuropea KAR(R)A / GAR(R)A 'pietra', Studi Etruschi, IX (1935), pp. 133-151 y X (1936), pp. 165-189 (su estilo etimológico, bastante atrevido y más corriente de lo deseable en esta materia difícil, recibe la dura crítica de J. R. CRADDOCK, Latin legacy versus substratum residue: The Unstressed "Derivational. Suffixes in the Romance Vernaculars of the Western Mediterranean [Berkeley-Los Ángeles: University of California Press, 1969], p. 42). Al Carranza vizcaíno se refiere Tovar en estos términos: "Carranza, nombre de un pueblo de Vizcaya y de tres aldeas asturianas, puede ponerse junto a *Caranto $-a$, hidrónimo repetido en Inglaterra Carrant, Carant, etc.; Irlanda Carad, Saboya Chéran, la Charente en el Saintonge, Charantonne, río de Normandía. [...] Carranza es una formación en "-nt-» muy característica de las antiguas capas de indoeuropeo, pero su raíz, no cabe duda, es anterior, preindoeuropea"; cf. A. TOVAR, Cantabria prerromana o lo que la lingüística nos enseña sobre los antiguos cántabros (Madrid: Universidad Internacional "Menéndez Pelayo", 1955), p. 25; y "Topónimos con -NT- en Hispania y el nombre de Salamanca", Actas del V Congreso Internacional de Ciencias Onomásticas (Salamanca: Acta Salmanticensia, XI, 1958), pp. 107-108.

14 Cf. R. MENÉNDEZ PIDAL, Toponimia prerrománica bispana (Madrid: Gredos, 1952), p. 165. En cuanto al significado de este elemento, Tovar ("Topónimos con -NT-..., cit., p. 100) acepta que con él se indicarían, conjuntamente, ideas de dependencia y colectividad. Al análisis de Tovar (Krahe-Tovar) se refiere J. Hubschmid ("Toponimia prerromana", Enciclopedia Lingüística Hispánica, vol. I, pp. 485-486), quien destaca por su interés aquellos casos en que el sufijo se ha unido a raíces preindoeuropeas, así en Carranza. 
La investigación del período prerromano se desarrolla de un modo especialmente precario, menos por la insuficiencia de los métodos empleados que por la resistencia que a la investigación opone el objeto en sî ${ }^{15}$. Establecida la distinción básica entre toponimia prerromana y toponimia románica fundada en léxico de origen prerromano, advertimos que la toponimia carranzana de esta época que parece segura no es mucha, aunque su inventario comience significativamente por el propio nombre del Valle. A los ya citados pueden añadirse otros nombres de interpretación difícil, interesantes para los especialistas en lenguas prerromanas: por ejemplo, la serie de los Salduero, Salduraño y Salduria (lugares de montaña y zonas de pastoreo) que estimamos compuestos de sel 'pradería' y un lexema derivado de las raíces DOR-, DUR-, las cuales se hallan en muchos nombres de ríos europeos, incluyendo los hispánicos Douro / Duero, Duruelo o Duratón ${ }^{16}$. Por otra parte, formas como El Urrio, El Urro, La Gurria y Los Jorrios componen un grupo intrincado, posiblemente compuesto por raíces diversas parcialmente homófonas, algunas de ellas de origen prelatino, indoeuropeo y no indoeuropeo ${ }^{17}$. Este panorama, muy abreviado pero representativo de la toponimia prerromana en Carranza, permite subrayar similitudes en un área norteña amplia, y, en cambio, no facilita la relación con lo vasco, la cual queda reducida a lo preindoeuropeo más oscuro y antiguo, en la línea de lo sentado por Tovar, Caro Baroja y Michelena acerca de los límites occidentales de la lengua vasca a la llegada de los romanos a la Península (vid. supra). No hay otros testimonios onomásticos vascos que las huellas de algunos apellidos conocidos en

15 Cf. M. FAUST, "Cuestiones generales de toponimia prerromana", Actas del I Coloquio sobre lenguas y culturas prerromanas de la Peninsula Ibérica (Salamanca: Universidad de Salamanca, 1976), pp. 165-189.

16 Cf. A. Llorente Maldonado DE Guevara, "Esquema toponímico de la provincia de Salamanca: topónimos prerromanos", Strenae. Estudios de filologia e bistoria dedicados al profesor M. García Blanco (Salamanca: Universidad de Salamanca, 1962), p. 319; A. DauzaT, op. cit., pp. 127-131. Compárese el Salduero de Carranza con Salduero de Soria (diócesis de Osma), en la margen izquierda del Duero.

17 Muy brevemente, para el esclarecimiento etimológico de este grupo complejo, hay que contar con los posibles derivados del latín HORREum, orrio en Autoridades, voz que sitúa "en las montañas"; el vascuence urra 'avellana', el(b)orri 'espino' y navarro orre 'enebro'; cf. L. Michelena, Apellidos vascos (San Sebastián: Txertoa, 1973) (3. ${ }^{2}$ ed. aumentada y corregida), p. 160; J. M. IRIBARREN, Vocabulario Navarro (Pamplona: Institución "Príncipe de Viana", 1984) (2. ${ }^{a}$ ed.), p. 383. Y, además, debe considerarse la posible raíz preindoeuropea URR- 'cerro'; cf. J. HUBSCHMID, op. cit., pp. 460-62 y 480481. Sólo así es posible dar cuenta de un copiosísimo grupo de topónimos (y léxico dialectal) que puede comprender desde los Urriello y Jurrio asturianos al aragonés Urrea. 
varias denominaciones del tipo La Caseta de Zabala, El Molino de Chávarri o La Huerta de Ibarrondo, que designan propiedades y que recuerdan sobre todo el afincamiento en el Valle de gentes vascongadas, vizcaínas, guipuzcoanas y navarras, en relación con la explotación de las numerosas ferrerías de la zona, la tala de árboles y el carboneo ${ }^{18}$.

\subsection{Notas de bistoria vizcaina}

Lo que la toponimia de Carranza y Las Encartaciones nos muestra es un espacio románico afín a los territorios vecinos montañés, alavés y burgalés norteño, en concordancia con la historia de la comarca. Tal vinculación se aprecia desde la primera mención escrita que tenemos relativa al territorio, la cual se refiere a la actividad repobladora de Alfonso I a mediados del siglo viII:

Eo tempore populantur Asturias, Primorias, Liuana, Transmera, Subporta, Carrantia, Bardulies, qui nunc vocitatur Castella [...] Alabanque Bizcai, Alaone et Urdunia a suis reperitur esse possesas... ${ }^{19}$.

De acuerdo con el párrafo, el rey asturiano ejercía un poder político y militar desde el valle del Sella al occidente vizcaíno y parte del norte de la provincia de Burgos ${ }^{20}$. De modo que, cuando Las Encartaciones (Carranza y Sopuerta) aparecen en la Historia, lo hacen unidas a las comarcas románicas vecinas, en oposición a Vizcaya, Orduña y Ayala. La dualidad se ahonda aún porque, además, según indica la Crónica, Alfonso I llevó consigo a tierras de Carranza, Sopuerta y Castilla, gentes de

18 No se trata, pues, de toponimia prerromana. La huella de la onomástica antroponímica vasca no prerromana se ve de modo análogo en las comarcas vecinas no vizcaínas, santanderinas y burgalesas que, como Las Encartaciones recibieron desde el siglo XVIII y, sobre todo, en el XIX, un buen número de inmigrantes vascos como muestran los estudios de J. ORTEGa VALCÁRCEL, La transformación de un espacio rural: las montañas de Burgos (Valladolid: Universidad de Valladolid, 1974), pp. 149 y ss.; y M. C. GONZÁlez ECHEGARAY, "Aportación al estudio de las ferrerías montañesas", Publicaciones del Instituto de Etnografía y Folklore "Hoyos Sáinz", V (1973), pp. 131-211.

19 Cita tomada de J. A. GARCÍA DE CORTÁzAR, B. ARIZAGa et alii, Vizcaya en la Edad Media (San Sebastián: Haranburu, 1985), vol. I, p. 25; el mismo texto (en sus versiones rotense y ovetense) en A. E. DE MAÑARICÚA, Vizcaya, siglos VII al XI. Los orígenes del Señorio (Bilbao: Caja de Ahorros Vizcaína, 1984), pp. 77 y ss.

20 Cf. A. BARBero y M. Vigil, La formación del feudalismo en la Península Ibérica (Barcelona: Crítica, 1986) (4.a ed.), pp. 279 y ss. 
tradiciones mediterráneas. Como ha señalado J. Á. García de Cortázar, “...si la aportación de los emigrantes del Ebro alto y medio fue, sin duda, una serie de modelos culturales de raíz mediterránea, entendidos desde la alimentación a la lengua romance y la fe, quiere decir que los mismos empezaron a aclimatarse en los valles de las después llamadas Encartaciones, mientras que la Vizcaya nuclear quedaba inicialmente al margen, esto es, euskara y pagana" ${ }^{21}$.

En la Edad Media, las tierras hoy vizcaínas aparecen repartidas en dos espacios episcopales, cuyo límite coincide con el del Cadagua-Nervión que, ya se ha visto, constituye una vieja línea fronteriza tribal ${ }^{22}$. Cuando en los siglos X y XI se dibuja con cierta claridad la geografía eclesiástica de la zona, el antiguo terriorio caristio, esto es, parte de Vizcaya y de Álava (al este, aproximadamente, de la línea Nervión-Cadagua-Omecillo), se incluyó en el obispado de Álava, mientras que el autrigón, que abarcaba Las Encartaciones, tuvo la sede del suyo en Valpuesta (en la cuenca alta del Ebro, territorio de Miranda de Ebro) que dirigirá la vida espiritual de la región ${ }^{23}$. Valpuesta, sede oficial de obispos desde 804 hasta 1087 (con un breve paréntesis najerense), heredó los territorios que en Vizcaya y Álava había tenido la primitiva diócesis de Oca ${ }^{24}$, la cual revive fugaz-

21 J. A. García de Cortázar, B. Arizaga et alii, op. cit., vol. I, p. 35.

22 Menéndez Pidal señaló la continuidad de los límites étnicos prerromanos en las demarcaciones administrativas eclesiásticas del territorio vasco ("Introducción al estudio de la lingüística vasca", en Curso de Lingüística [San Sebastián: Eusko Ikaskuntza, 1921], p. 28). Por su parte, Mañaricúa recuerda que fue Arturo Campión quien observó por primera vez la coincidencia de las áreas lingüísticas en el País Vasco (dialectos vascos y romance) con la antigua geografía tribal; cf. E. DE MAÑARICÚA, “Obispados en Álava, Guipúzcoa y Vizcaya hasta fines del siglo XI", en Obispados de Álava, Gipúzcoa y Vizcaya hasta la erección de la Diócesis de Vitoria (Vitoria: Eset-Seminario de Vitoria, 1964), pp. 12-13.

23 Cf. L. SERRANO, El Obispado de Burgos y Castilla primitiva, desde el siglo $\mathrm{V}$ al XIII (Madrid: Instituto "Valencia de D. Juan", 1935-1936), vol. I, pp. 80 y ss. El documento fundacional de Valpuesta (a. 804), con la descripción de los términos que se repueblan o "apresan", como parte de la dotación eclesiástica original, fue publicado por L. BARRAU-DIHIGO, "Chartes de l'Église de Valpuesta du IX au IX siècle", Revue Hispanique, VII (1900), n. ${ }^{\circ}$ I, pp. 282-288.

24 La primera mención oficial de un obispo de Oca es de 589, en el III Concilio de Toledo, aunque Serrano cree que la sede remonta al siglo IV. Según L. Serrano (op. cit., vol. I, pp. 16 y ss.), en tiempos romanos, la diócesis de Oca habría comprendido el territorio de Mena, Sopuerta, Carranza, Castro Urdiales, Laredo y todo el valle del río Asón, lindando por Trasmiera con la de Astorga; y, además, la mayor parte de Álava, Berrueza, las Amézcoas y la zona de Calahorra y Logroño; cf. también E. MañaricúA, "Obispados...”, cit., pp. 10-18. 
mente en el siglo $\mathrm{XI}^{25}$. En 1087, Alfonso VI transforma definitivamente el obispado de Oca en el de Burgos, y, cuando en 1754 Santander se desgaja de Burgos, Las Encartaciones pasaron a pertenecer a la nueva sede, durante más de un siglo, hasta su integración en la de Vizcaya a mediados del XIX.

Verosímilmente fue en el siglo XIII cuando los Haro incorporaron Las Encartaciones al llamado "mayorazgo de Vizcaya", dentro del cual siguieron manteniendo instituciones propias. Todavía en 1452, el Fuero Viejo suele referirse así a los vizcaínos: "...los dichos vizcaínos, así los de las villas como los de las tierras llanas de Vizcaya, e durangueses e de Las Encartaciones..... La peculiaridad de estas cuatro entidades diferenciadas, física e institucionalmente, se mantuvo durante siglos ${ }^{26}$. Los encartados conservaron la junta de Avellaneda (Sopuerta), y se rigieron por un fuero de uso y costumbre que se había reducido a escritura en 1394. Tras varios intentos de unión protagonizados por algunos concejos de la comarca durante los siglos XVII y XVIII, en 1799 se produjo la fusión definitiva de Las Encartaciones en Vizcaya. En palabras de Labayru, "Bizcaya trató a menudo de que la Encartación no se portase con tanto aislamiento del Señorío y que así como las villas y el Duranguesado tenían más contacto y unión con Bizcaya la nativa y propia, no pudo conseguir, conservándose distinta y separada en territorio, privativa jurisdicción y gobierno hasta finalizar el siglo pasado" ${ }^{27}$.

Como muestra de la compleja adscripción de Las Encartaciones a Vizcaya, vemos que en la división provincial vigente en España a lo largo

25 En el privilegio del año 1068 sobre derechos de pastoreo, pesca, aprovechamiento de canteras y bosques, que señala las tierras en que el obispo de Oca podrá ejercitarlos, se citan los pastos "de Castella Vetula et in Karrança et usque ad Somrostro e in montibus de Transmiera" (cf. Serrano, op. cit., vol. III, pp. 31 y ss.).

26 Cf. GARCía de CorTázar, ARIZAGa et alii, op. cit., vol. IV, p. 62 y vol. I, pp. 174 y ss. Para todo lo tocante a la creación de los perfiles físicos e institucionales del Señorío de Vizcaya, remitimos al pormenorizado estudio de G. MONREAL y CíA, Las Instituciones puíblicas del Señorio de Vizcaya (basta el siglo XVII) (Bilbao: Diputación de Vizcaya, 1974).

27 E. DE LABAYRU, Historia General del Señorio de Vizcaya, reproducción facsimilar de la 1." ed. (1895-1900) (Bilbao: La Gran Enciclopedia Vasca, 1967-1969), vol. II, pp. 542-543. Las relaciones entre el Señorío y Las Encartaciones se vieron afectadas por varios conflictos, principalmente los derivados de los repartimientos o contribución a los gastos comunes. También fue un problema la participación en los Regimientos Generales, pues Las Encartaciones concurrían a Guernica con un solo apoderado y voto para todo el bloque de concejos y valles de la comarca, situación de manifiesta desigualdad que evidencia lo singular de la inserción del territorio en el complejo señorial (cf. G. MONREAL y CíA, op. cit., pp. 255-261). 
del Antiguo Régimen (la recogida por orden de Floridablanca en 1785), Encartaciones de Vizcaya se contaban como provincia al lado de Álava, Guipúzcoa y Vizcaya, aunque fueron pronto suprimidas como tales, entre 1802 y 1812, con las de Toro y Nuevas Poblaciones. Luego, en la división de Bauzá de 1813, las Provincias Vascongadas incluyen, como siempre, Vizcaya, Guipúzcoa, y Álava, pero el partido de Carranza se agrega a Santander. No obstante, estas fluctuaciones no se reflejaron en el decreto de 1833 , obra de Javier de Burgos ${ }^{28}$.

Los estudios onomásticos no pueden prescindir del saber adquirido por la investigación histórica a partir de toda otra suerte de datos, pues la historia proporciona un marco de conocimientos que es pórtico y guía indispensables en el desentramado de la estratigrafía toponímica.

\section{TOPONIMIA E HISTORIA DE LA LENGUA}

La cronología lingüística es la dimensión fundamental de la toponimia, cuyos testimonios se distribuyen conforme a la especificidad lingüistica de las correspondientes áreas dialectales que, por su parte, ellos también contribuyen a perfilar y conocer. Así desempeña la toponimia su "función robustecedora de la tradición lingüística" ${ }^{29}$.

Para investigar la historia lingüística del occidente de Vizcaya, a falta de otros documentos, la toponimia ofrece un testimonio irreemplazable. $\mathrm{Y}$ en la homogeneización actual de las variedades rurales, la toponimia menor, por su apreciable cantidad y por su estrecha vinculación con el habla permite una indagación dialectal que difícilmente podría realizarse por otros medios ${ }^{30}$. La fiabilidad de las conclusiones lingüísticas que pue-

28 Cf. A. M. CALERO AMOR, La división provincial de 1833. Bases y antecedentes (Madrid: Instituto de Estudios de Administración Local, 1987), pp. 15-18 y 20; el caso vasco es analizado con detalle en las pp. 95-102.

29 Son palabras de J. Corominas (op. cit., vol. I, p. 122). Muchos capítulos de la historia de las lenguas están ligados a sus documentaciones: Orígenes del español es nuestro más ilustre ejemplo, y, como se sabe, la historia de la lengua vasca ha de recurrir casi exclusivamente a la onomástica para obtener los datos básicos durante el período que va, más o menos, del año 900 a 1500; cf. L. Michelena, "Toponimia, léxico y gramática, Fontes Linguae Vasconum, III (1971), p. 241; G. B. PelleGriNI, "Teoria ed esperienza nella ricerca toponomastica", Archivio per l'Alto Adige, LXXV (1981), p. 32. Recordemos que G. RoHLFs ofrece una selección de arcaísmos lexicales sólo documentados en topónimos: "Aspectos de toponimia española", Antroponimia e toponomastica nelle lingue neolatine: aspetti e problemi (Tübingen: G. Narr, 1985), pp. 38-40.

30 Como señala J. R. MORALA, «...el análisis de la toponimia menor, aunque sea más complejo por la falta de inventarios organizados, aporta datos realmente 
den extraerse del análisis de topónimos crece con la densidad del inventario que se estudia. Como contrapartida, un análisis toponímico exhaustivo no suele permitir abarcar un territorio muy extenso, como en el caso que aquí presentamos: el corpus de la toponimia carranzana, del que proceden los datos que expondremos, ha sido elaborado con testimonios orales y escritos de varias épocas. A los informes de la encuesta hemos sumado los procedentes de repertorios catastrales (desde el último cuarto del siglo XIX hasta hoy), legajos del AHPV ${ }^{31}$ (de los siglos XVIII y XIX, principalmente), mapas y bibliografía local, con los que se ha organizado un inventario de varios miles de nombres que permite esbozar una imagen muy completa de las características principales de la tradición lingüística de este territorio ${ }^{32}$. Aunque aquí sólo podremos ofrecer algunos ejemplos, son testigos típicos y no singulares o aislados, escogidos desde el conocimiento del conjunto ${ }^{33}$.

\subsection{Estratos léxicos en la toponimia de Carranza}

Tal vez la exigencia más difícil con la que se enfrenta el estudioso de la toponimia sea determinar con alguna exactitud la cronología de los datos lingüísticos que maneja. Las dificultades crecen cuando ni siquiera se dispone del soporte de una documentación antigua que permita retroceder al menos hasta la Edad Media, de modo que la fecha ante quam se puede saber con seguridad que tal topónimo existe ya se aproxima tanto al presente que le priva de verdadero interés histórico. Sin embargo, a menudo, la suma de indicios lingüísticos y extralingüísticos proporciona un carácter de suposición razonable a las conjeturas. Con este objetivo, trata-

esclarecedores sobre el pasado lingüístico del área geográfica en que se usa. [...] La toponimia menor se convierte así en un eslabón intermedio necesario para explicar la divergencia entre los porcentajes de uso más antiguos (documentación, toponimia mayor...) y los usos actuales de que dan cuenta los estudios de dialectología" ("Toponimia y diacronía. Los sufijos diminutivos en León", Lletres Asturianes, XIX [1986], pp. 82-83).

31 Archivo Histórico Provincial de Vizcaya, sección judicial de la Tenencia del Corregimiento de Valmaseda.

32 I. ECHEVARRÍA IsUSQuiza, Estudio lingüístico de la toponimia de Carranza (Universidad del País Vasco, 1996 [tesis doctoral inédita]).

33 Del resto de Las Encartaciones poseemos datos más fragmentarios, principalmente tomados de las hojas del Mapa Topográfico Nacional, escala 1: $50.000 \mathrm{y} \mathrm{J} . \mathrm{M}$. DE SASÍA, Toponimia euskérica de las Encartaciones de Vizcaya (Bilbao: Gráficas Ellacuría, 1966). 
remos de señalar los hitos cronológicos más claros en el proceso de sedimentación lingüistica de la zona.

\subsubsection{Toponimia romana}

En Vizcaya no abundan las huellas arqueológicas romanas, que, sin embargo, tampoco faltan ${ }^{34}$, en relación con intereses mineros, de navegación, y con algunas villas o asentamientos agropecuarios del interior. En Las Encartaciones hay restos romanos epigráficos, y se han recuperado dos tesorillos (en Güeñes y Carranza) constituidos por monedas de la época de los Flavios y Antoninos (siglos II y III), cuando la influencia romana se dejó sentir más en el territorio ${ }^{35}$. Por todo ello, aunque la historia, tal y como la conocemos, no anima la esperanza de encontrar muchos topónimos de esta época en la zona, tampoco niega esa posibilidad, y la lingüística, mediante la comparación con toponimias vecinas mejor documentadas, puede mostrar algunas vías de investigación.

Entre los indicios lingüísticos manejados para fechar topónimos de esta época, uno de los más conocidos es la identificación de los diversos procedimientos para denominar las propiedades con el nombre de su posesor, bien con sufijos o mediante el genitivo, recurso que abarca un largo período latino-medieval. Un topónimo carranzano, Montañán ${ }^{36}$, parece

34 "La relativa calidad de las muestras recogidas merecen sosegada atención y estudio en aras de una más científica explicación histórica de la peculiar presencia de Roma en estas tierras norteñas", afirman A. Rodríguez Colmenero y M. C. Carreño (Epigrafía vizcaína. Revisión, nuevas aportaciones e interpretación histórica", Kobie, XI [1981], 81). Según C. García Merino (op. cit., 351), la investigación de la presencia romana en territorio vasco ha estado condicionada por prejuicios y abandonada en un cierto descuido; sin embargo, podemos afirmar que en los últimos veinte años la arqueología de este período y del altomedieval se ha desarrollado notablemente (cf., por ejemplo, las obras citadas en la nota siguiente).

35 Se han catalogado cuatro inscripciones de las que tres son viarias y una funeraria. Las primeros se localizan a lo largo del trazado de la vía Pisoraca-Flaviobriga y corresponden a dos momentos: la más antigua, datada en el año 85 , procede del puerto de Las Muñecas; las dos restantes, de Valmaseda y Ocharan (Zalla), corresponden a los tiempos del emperador Maximino, en torno al año 238 d.C. Además, en el apartado referente a epigrafía funeraria, hay que mencionar la estela de Zaldu en Gordejuela, bloque de arenisca de forma cuadrangular, cuyo texto comienza con una invocación a los dioses Manes. Cf., entre otros trabajos, J. GORROCHATEGUI y M. J. YARRITU, Carta arqueológica de Vizcaya. Segunda parte: materiales de superficie (Bilbao: Universidad de Deusto-Diputación de Vizcaya, 1984), pp. 125-127; J. A. BARRIO LOZA et alii, Bizkaia. Arqueologí, urbanismo y arquitectura bistórica (Bilbao: Universidad de Deusto-Diputación Foral de Vizcaya, 1991), vol. III, pp. 348 y ss. 
responder inequívocamente al modelo de topónimo antroponímico romano. Hay razones para suponer que este nombre representa el genitivo de un adjetivo MONTANIANUS, formado sobre el antropónimo MONTANUS, que especificaría a un sustantivo masculino elidido, como AGER O FUNDUS ${ }^{37}$. Montañana, despoblado en Burgos ${ }^{38}$, es formación femenina análoga. Además, hallamos Montaño en Abanto y Ciérbana (Encartaciones), con Montaño y Montaos en La Coruña ${ }^{39}$.

\subsubsection{Toponimia romance. A) Léxico más antiguo}

Pero la toponimia carranzana está mayoritaria y característicamente formada a base de léxico romance, y en la toponimia romance es bastante difícil distinguir estratos. Como hemos dicho, la historia lingüística, que ayuda a veces a deslindar lo más antiguo de lo nuevo, puede señalar una cronología, aunque relativa, principalmente cuando conoce la fecha de aparición y desaparición de un término de la lengua viva que tenga su correspondencia en algún topónimo ${ }^{40}$. Ahora bien, al fechar nombres tomando como criterio la época de su desaparición de la lengua común, no debe descuidarse el hecho de que elementos que resultan arcaizantes en el español común actual pueden no serlo en el habla a la que corres-

36 Es hoy un caserío aislado; en algunos documentos del AHPV se cita "la casería de Montañán del lugar de Cezuran (AHPV 1776, 1788, etc.), que significa que en la articulación del poblamiento, se considera a Montañán un núcleo poblado menor perteneciente a Cezura, que a su vez es uno de los barrios del concejo de Haedo.

37 El sufijo -ANUs es el procedimiento morfológico habitual para formar los adyacentes antroponímicos del nombre del fundus, núcleo rústico de menor categoría que el indicado por el correspondiente femenino, -ANA, que señala la existencia de villas más importantes, urbanas. El fundus comenzó a evolucionar hacia una aldea compleja o vicus desde fines del siglo III, con las primeras amenazas de invasión bárbara en el norte, aunque tal transformación sólo parece sistematizarse después del año 1000 (cf. J. Caro Baroja, Materiales..., cit., pp. 92 y 63).

38 Datos hallados en los trabajos de B. OsABA y RUIZ DE ERENCHUn, "Poblados, monasterios y castillos desaparecidos en la provincia de Burgos", Boletín de la Institución "Fernán González", CLXVI (1966), p. 30; J. PÉREZ CARMONA, "La historia y la geografía burgalesa reflejadas en su toponimia", Boletin de la Institución "Fernán González", CLXIII (1964), p. 241.

39 M. Dolç menciona el apellido Montano, representante directo del antropónimo MONTANUS (Antroponimia latina”, Enciclopedia Lingüística Hispánica, vol. I, p. 409); cf. también L. MichelenA, "Nota marginal..., cit., p. 22, a propósito de Mandojana.

40 Cf. A. MONTENEGRo DuQue, "Toponimia latina", Enciclopedia Lingüística Hispánica, vol. I, p. 504. 
ponde la toponimia que analizamos. En este caso, si la referencia es exclusivamente la lengua común, erraremos a menudo calificando de arcaísmos toponímicos formas que tal vez mantienen plena vigencia en el léxico regional; y no apreciaremos el valor que para la caracterización de esas hablas supone el mantenimiento de formas que el español general ha superado en su evolución ${ }^{41}$.

Por ejemplo, la toponimia castellana guarda abundante recuerdo de la preposición $s o$, cuyo uso parece ya anticuado en el siglo $\mathrm{XVI}^{42}$, pero en Carranza, los ejemplos son copiosísimos: Solabarrera, Solabrena, Sobustillo, El Socalero, Socamino o Solcamino, Socampillos, Solcampo, Socasa y Solacasa, El Solcuarto, Socubio, Solafragua, Solahuerta, Solbuerto o Sobuerto, Solaiz, Solajaza, Solindar, Solinde y Solalinde, Solasllamas, Solallosa y Solasllosas, Somatienzo, Sonovales, Sopeña, Solapeña, Solaspeñas, Sopomar, La Sorrasa, Sorriba, El Sorribero, Solrio, Solasalce, Sotarrero, Solaviña, Solvivero, etc. Con ser sólo una muestra, es suficientemente cuantiosa para obligarnos a dudar que todos estos topónimos sean anteriores al siglo XVI, y a suponer que más bien indican que el desuso de so en el habla no puede ser muy antiguo en nuestra zona ${ }^{43}$.

Análogamente, la toponimia de estrada, que, con la acepción 'camino entre dos tapias, cercas o setos', figura en el DRAE (s.v., 2. ${ }^{a}$ ac.) como vizcaína, muestra la disyuntiva señalada entre arcaísmo y regionalismo. En Carranza encontramos abundantes testimonios de lugares denominados $\mathrm{La}$ Estrada, Estradillas y El Estradón. Parece que en la Península Ibérica, estrada 'camino' era voz de escasa frecuencia ya en La Edad Media, aunque estrada (latín STRATA (VIA) 'camino empedrado') se halla en textos

41 En el caso de los arcaísmos léxicos, pueden distinguirse, al menos, aquellos que C. Corrales Zumbado denomina "falsos arcaísmos" o "arcaísmos parciales", de difusión muy general en la geografía actual del idioma (aunque no en la norma castellana), de los auténticos arcaísmos, de difusión más restringida que puede llegar a circunscribirse a los límites de un habla local ("Tipología de los arcaísmos léxicos", Actas del II Simposio Internacional de Lengua Española [Gran Canaria, 1984], pp. 131-143).

42 Cf. J. Corominas y J. A. Pascual, Diccionario Crítico Etimológico Castellano $e$ Hispánico (Madrid: Gredos, 1980-1991) (en adelante, DCECH), s.v. so; M. ALVAR y B. PotTier, Morfología bistórica del español (Madrid: Gredos, 1983), pp. $304-306$ y $353-354$.

43 Los bables son ahora, quizá, centro de la escasa vitalidad de la preposición que, sobre todo, abunda como prefijo en la toponimia, con el valor de 'bajo, debajo de', igual que en otras regiones de España. Cf. J. NEIRA, "Origen de la forma prefijal /so/ en topónimos asturianos", Boletín del Instituto de Estudios Asturianos, XCV (1978), p. 577; J. NeIra y M. R. PIÑEIRO, Diccionario de los Bables de Asturias (Oviedo: Instituto de Estudios Asturianos, 1989), p. 325. 
jurídicos catalanes, y en portugués parece haber sido más popular, como en Galicia, donde estrada 'carretera' sigue vivo (vid. DCECH, s.v. estrado). Volviendo a Carranza, todavía en las Ordenanzas municipales del año 1855 se dice que "los vecinos que tengan heredades a linde de caminos y estradas que aderecen lo que tocare a la heredad de cada uno" ${ }^{44}$; lo que confirma la vigencia apelativa de estrada, bastante más allá de la Edad Media, en este rincón vizcaíno. Por otro lado, los numerosos testimonios toponímicos montañeses y alaveses permiten una interpretación análoga para estas zonas. Si el burgalés Estramiana puede ser recuerdo aislado de un nombre de época altomedieval o romana (STRATA MEDIANA), los numerosísmos La Estrada y La Estradilla de Álava se deben al apelativo romance; en Ayala, estrada designa un 'camino de carros entre caseríos', al igual que en la zona oriental de Cantabria ${ }^{45}$, de donde habrá surgido, mayoritariamente, la muy copiosa toponimia montañesa de estrada. De este modo, los datos aportados acerca de Cantabria, Vizcaya y Álava colman parte del vacío entre Galicia y Cataluña, y confirman la vitalidad regional de *STRATA en iberorromace ${ }^{46}$.

En cambio, sí parecen verdaderos arcaísmos léxicos conservados en la toponimia carranzana algunos términos muy comunes en la documentación medieval seudolatina, que, aunque se registran en la onomástica, no parecen haber dejado huella en el léxico popular. Por ejemplo, Cezura (uno de los barrios del concejo de Haedo, lugar elevado y con comunicaciones difíciles) es nombre poco transparente, pero vuelve a hallarse en otras partes: en Las Encartaciones hallamos otro Cezura en Trucíos; hay Mataseñas y Cezura en la Reserva Nacional del Saja, Cantabria; Cezura en Palencia (p.j. de Cervera de Río Pisuerga) y Cesuras en Lugo y La Coruña. Los topónimos gallegos Cesuras y la variante escrita Cesura (registrada en índices catastrales de principios de siglo) sugieren la posibili-

${ }^{44}$ M. LÓPEZ GIL, Valle de Carranza (Bilbao: Gráficas Garvica, 1975), p. 36. Atestiguamos su uso en los legajos del AHPV: «...y enfrente de la estrada que baja del lugar de Biañes....; "...de la estrada que está saliendo del lugar de La Rebilla.... (AHPV 1753 , documento sobre reparación de puentes y caminos). Emplea esta voz el costumbrista Trueba: "...se encontraban muy bien paciendo a la sombra en los ribazos de la estrada..." (El fuerte de Ocharan, apud N. VICARIO DE LA PEÑA, El Muy Noble y Leal Valle de Carranza [Bilbao: Junta de Cultura de Vizcaya, 1975], p. 280).

45 Cf., para Álava, F. DE BARRENENGOA, op. cit., vol. III, p. 172; para Cantabria, J. P. SÁNCHEZ Llamosas, El habla de Castro (Madrid: Irenea, 1982), p. 110; también en Navarra, estrata 'calleja' (J. M. IRIBARREN, op. cit., p. 240).

46 Sin embargo, La Estrada de la toponimia asturiana no encuentra correspondencia en el léxico regional, que sólo parece conocer estrar 'hacer con el estru o rozu las camas para las bestias'; cf. J. NEIRA y M. R. PIÑEIRO, op. cit.; s. $v$. 
dad de que Cezura sea variante de cesura, con asimilación de sibilantes ${ }^{47}$. El castellano cesura, latín CAESURA 'corte', 'cesura', se registra por primera vez en Alonso de Palencia y en Nebrija, quien emplea la palabra como puramente latina, sin traducción castellana ( $D C E C H$, s.v.). Un latinismo tal carece de sentido en la toponimia, máxime si consideramos que se trata exclusivamente de un tecnicismo literario ( $D R A E$, s.v.). Sin embargo, es usual en el latín medieval de los cartularios: a...et in illa clausa cum suos solares cum suas cesuras vel genera arborum.... ${ }^{48}$. Así, el topónimo carranzano y los otros citados, cuyo sentido podría ser, entonces, el de 'espacio talado', parecen vestigios de un apelativo tardolatino que quizá tuvo alguna vigencia en las hablas romances medievales ${ }^{49}$.

La complejidad histórica de los testimonios toponímicos puede ilustrarse mediante los derivados de PORCILE 'pocilga': El Porcil y Porciles, topónimos de Carranza registrados también en la toponimia asturiana y montañesa ${ }^{50}$, parecen las formas medievales correspondientes a la toponimia más reciente del regionalismo borcil / burcil 'pocilga', voz regional derivada igualmente de PORCILE ${ }^{51}$. Por tanto, los topónimos de Carranza llamados

47 Tal vez, como en cereza, ceniza, cerveza y otros, la - $z$ - moderna se debe a un fenómeno de dilación corriente (cf. $D C E C H$, s.v. cereza).

48 Cartulario de Santillana, ms. S. XIII, apud M. AlOnso, Diccionario medieval español (Salamanca: Universidad Pontificia, 1986), vol. I, p. 686, quien define cesura como sigue: "Corte, producto de cortar madera en los bosques".

49 J.M. Piel ha interpretado así el topónimo gallego "Ponte Cesures (ant. -as): caesuras 'cortes de vegetação; aceiras'" ("Sobre a legitimidade do conceito de latinidade vulgar galaica", Actas de la Primera Reunión Gallega de Estudios Clásicos [Santiago de Compostela, 1981], p. 257). Por otro lado, cesura tiene, lejos del tecnicismo literario que acoge el $D R A E$, cierta vida popular: en las hablas pasiegas, 'herida del ganado' (R. J. PENNY, El babla pasiega: ensayo de dialectología montañesa [Londres: Tamesis Books, 1969] p. 251); y es voz común andaluza: "cisura, raja o herida" (A. AlCALÁ VENCESLADA, Vocabulario andaluz [Madrid: Gredos, 1980], p. 150).

50 En algunos casos, desde el siglo X: una braña llamada Porciles aparece entre las donadas por Alfonso III a la iglesia de Oviedo, en Naranco, el año 905 (apud A. C. Floriano, Diplomática española del periodo astur [Oviedo: Instituto de Estudios Asturianos, 1949-1951], vol. II, p. 296); hay varios lugares llamados así en Asturias (M. A. ARIAS, "Toponimia menor del Concejo de Salas", Boletín del Instituto de Estudios Asturianos, XL [1960], p. 246) y en Cantabria.

51 Con $b$ - contaminada por brosquil, según el DCECH (s.v. puerco), que señala lo siguiente: "Brosquil, aragonés 'redil', parece haber significado primeramente 'cercado de maleza en que se encierra el ganado' y derivar de BRUSCA 'leña menuda'. Como brosquil se usa en Aragón, Soria y en el catalán del Maestrazgo, no entendemos de qué manera puede haber influido sobre borcil, cuya geografía es completamente distinta. Borcil 'cubil' es voz montañesa (A. GARCía LOMAS, El lenguaje popular de las montañas de Santander [Santander, 1949], p. 87); "pocilga, zahúrda, cochiquera. Cuarto 
El Borcil, aunque corresponden a la misma base etimológica que Porciles, pertenecen a estratos léxicos diferentes, de los que este último es más antiguo, tal vez romano, pues hay etimología latina pero no apelativo romance. De modo que el caso de Porcil / Borcil muestra la riqueza cierta de informaciones léxicas que la toponimia atesora: por una parte, proporciona testimonios históricos de determinado tipo léxico y, por otra, atestigua la amplitud de la difusión geográfica de ciertas voces dialectales.

\subsubsection{Toponimia romance. B) Superposiciones léxicas}

La proyección geográfica de la historia de las lenguas se descubre mejor en la toponimia que en el léxico, porque la onomástica es más rica en formas, al congregar lo nuevo y lo viejo en un mismo plano: que arroyo "Caudal corto de agua, casi continuo" (DRAE, s.v.) resulta ya desusado en el habla de nuestra comarca se ve en ejemplos tan elocuentes como $E l$ Regato del Arroyo (en Soscaño) y El Regato de Los Arroyos (en Lanzasagudas); sin embargo, su huella relativamente abundante en la toponimia muestra que no siempre fue así ${ }^{52}$. La pugna con regato, que hoy designa 'arroyo' en el habla del occidente vizcaíno ${ }^{53}$ puede interpretarse como el encuentro de dos corrientes de procedencia geográfica diversa, una castellana y meridional, y otra que llamaremos "leonesa", simplemente más occidental. Pues, como ha señalado Llorente Maldonado de Guevara, "la distribución geográfica de las distintas denominaciones registradas del sig-

o apartado en la bodega para estabular el chon. Casilla para guardar los chones. Aprisco para guardar el ganado lanar y cabrío" (J. P. SÁNCHEZ LlaMOSAS, op. cit., p. 57); en la comarca pasiega, burcil (R. J. PENNY, op. cit., p. 299). También se conoce en Mena, Burgos (F. GonZÁlEZ OlLÉ, "Características fonéticas del Valle de Mena", Boletín de la Real Academia Española, XL [1960], pp. 73-74). En Carranza, borcil designa hoy, principalmente, un lugar de la cuadra en donde se aparta a los corderos.

52 En Carranza encontramos el topónimo El Arroyo (designando terrenos, no arroyos) y el plural Los Arroyos, los dos en varios lugares del Valle; es término de referencia en Entrambosarroyos / Entrearroyos / Trambosarroyos / Ambosarroyos, de Biáñez; además de derivados como El Arroyuelo y El Arroyón. De otros puntos de Las Encartaciones podemos citar El Arroyo de Valmaseda, Arroyos de Sopuerta y Arroyuelos de Trucíos.

53 Algunos ejemplos interesantes de su uso apelativo en los legajos del AHPV son los siguientes: "...un molino harinero que mis partes quisieron construir [...] y aguar de un regato o arroyuelo..." (AHPV 1779); "...que también estuvieron atascados por habérseles roto el eje en un regato o barranca.... (AHPV 1854); el habla conoce el derivado regatada con sentido análogo al de barrancada 'avenida de aguas de un regato en su parte más caudalosa'. 
nificado 'arroyo' nos muestra claramente que regato (y variantes) es la denominación característica, y dominante, en el antiguo territorio leonés" ${ }^{54}$. Regato aparece en el nutrido grupo de lugares denominados $E l$ Regato (con la variante Reato) y los derivados La Regatilla, La Regatuca, El Regatio o El Regatillo y El Regatón, formas que se repiten en otros puntos de Las Encartaciones.

Por otra parte, la toponimia del 'helecho' reúne en Carranza los representantes de dos derivados de una misma raíz latina, fiLictum y "FILICARIA. Del primero, tenemos El Helechal y La Jelechosa, con las variantes orales balecho y (ha)lechal para designar la planta y el lugar en que abunda. Éste es el término corriente hoy, pero hay otro derivado sumamente frecuente en la toponimia, el otro colectivo de 'helecho': $E l$ Helguero (con numerosas variantes registradas por escrito y oralmente, entre las que destacamos bilguero, jilguero, jirguero, jiliero, bilberos, belberos, etc.), ya desusado, aunque aún se documenta en los siglos XVIII y $\mathrm{XIX}^{55}$. Un examen somero de la toponimia española recogida por Madoz (op. cit.) permite ver que las huellas iberorromances de *FILICARIA perfilan un territorio bastante definido, desde Galicia (Filgueira, Filgueiro, Felgueira, etc.) y Asturias (Felguera, Felguerina, etc.) a Cantabria (Helguera, Helguero, etc.); con nuestros datos, lo ampliamos hasta Bilbao, pues los derivados de ${ }^{*}$ FILICARIA llegan en Las Encartaciones hasta San Salvador del Valle, donde encontramos el topónimo Helguero ${ }^{56}$. Es interesante observar que toda la región cantábrica, hasta Asturias, presenta, igual que Carranza, un gran entrecruzamiento de las áreas de los derivados de FILICTU

54 Sobre la distribución geográfica de regato y arroyo, A. Llorente Maldonado de Guevara advierte que, en la zona sur del dominio leonés, arroyo representa la forma castellana; lo cual se ve confirmado por los atlas, pues arroyo es la forma prácticamente general en el occidente de La Rioja, Soria, Guadalajara, Cuenca y llega hasta Zaragoza y Teruel; es también la más frecuente en las provincias centrales andaluzas, repobladas por castellanos. Su extensión a zonas como Zamora, occidente de Salamanca y puntos de León, se debería, según Llorente, al prestigio que tiene como voz considerada correcta y estándar; cf. A. Llorente Maldonado de Guevara, "Las denominaciones correspondientes a las lexías de la lengua estándar arroyo, torrente, manantial y terreno pantanoso en Zamora, Salamanca y Ávila", RFE, LXIX (1989), pp. 254-257.

55 Es término corriente en los legajos del AHPV: “...que tenemos un sitio y belguero de árboles castañales ..." (AHPV 1703); "... cuatro rebollas con su belguero..." (AHPV 1710); "...diferentes árboles, belgueros y tierras..." (AHPV 1783); "...petición de bilgueros..., "...el bilguero se hizo seis partes..." (AHPV 1794); etc.

56 Otra región muy clara de derivados de FILICARIa es la oriental, catalano-aragonesa, y entre ambas se encuentra el castellano belecho. El adjetivo Felectosa se atestigua ya en 1142, y el colectivo felechar en 1177 (cf. DCECH, s.v. helecho). 
y los de FILICARIA, hecho apreciable tanto en la toponimia como en el léxico ${ }^{57}$.

\subsection{Dialectología}

Los estudios toponímicos han desarrollado su metodología a la sombra de la dialectología tradicional y sus prácticas cartográficas ${ }^{58}$. No sólo los métodos son semejantes sino que, frecuentemente, el investigador es el mismo: a...le toponymiste qui se rend sur le terrain et qui interroge les paysans pour connaitre l'emplacement exact de tel ou tel lieu-dit, pour en connaître le nom local, ne fait pas autre chose que de la dialectologie; et le dialectologue, pour connaître tel ou tel traitement phonétique qui n'apparaît plus très nettement dans un patois déjà oublié, est obligé de se réfugier dans l'étude des microtoponymes" ${ }^{59}$. La comparación con los datos provenientes de vocabularios y colecciones toponímicas regionales y locales de diversa índole, nos ha permitido fijar algunas correspondecias entre el léxico de Las Encartaciones y las regiones vecinas. Hemos hallado continuidad de tipos léxicos en un área iberorromance occidental amplia, y otra, más restringida, castellana norteña; ésta suele comprender,

57 En Cantabria hallamos jalechu y jalechera o jelechera 'helecho', y jelechar 'lugar con helechos' (A. GARCía LOMAS, op. cit., p. 207), además de los colectivos belguero y helgueral 'helechal', a veces definidos como 'erial' o 'terreno sin cultivar' (M. A. SÁIz BARRIO, Léxico cántabro [Santander: Tantín, 1991], p. 140; J. P. SÁNCHEZ Llamosas, op. cit., p. 122, etc.); en Asturias hay una gran fluctuación entre unos derivados y otros: felecbu, folechu, jelechu, fleitu, etc. 'helecho', se encuentran al lado de los colectivos felechal, felenchal, jelechal, y también fulgueiral (más datos fonéticos y semánticos reunidos por J. NEIRA y M. R. PIÑEIRO, op. cit., p. 190). En Álava se registran las voces falaguera y falagueral (G. LÓPEZ DE GUEREÑU, "Voces alavesas", Euskera, III [1958], p. 256), junto a los topónimos Helechal y Alechal.

58 Cf. T. L. MARKEY, "Crisis and cognition in onomastics", Names, XXX (1982), p. 132.

59 G. TAVERDET, "Onomastique et dialectologie", Actas del XVIII Congreso de Lingüistica y Filología Románica (Tübingen: M. Niemeyer), vol. IV, 1989, p. 480. La consideración dialectológica de la toponimia es un lugar común en la filología románica: "De la mayor importancia para la investigación fonética son aquellos nombres lpropios] cuya forma no tiene como base la lengua literaria, sino la evolución dialectal, decía Meyer-Lübke (Introducción a la Lingüística Románica [Madrid: Publicaciones de la $R F E, 1926]$, p. 374). El valor dialectológico del topónimo fue señalado por Rohlfs con claridad: "Es de particular importancia el estudio de los nombres de lugares para la geografía lingüistica. Mucho mejor que los documentos antiguos, muchas veces de difícil consulta, los topónimos nos pueden ayudar a fijar los términos geográficos en que una palabra se emplea o fue antes empleadan (op. cit., p. 50). 
con el norte de Burgos, Álava y La Rioja, pero la afinidad más constante y manifiesta se da con las hablas montañesas.

\subsubsection{Regionalismos extensos; occidentalismos}

En primer lugar, descubrimos algunos regionalismos de amplia difusión, que, sin caracterizar el vocabulario de un dialecto particular, pertenecen a un fondo léxico histórico español, aún conservado regionalmente. Este es el caso de lastra, palabra bastante extendida en la Península, sobre todo en el norte, desde el Pallars hasta Galicia y Tras os Montes ${ }^{60}$. Se encuentra en un nutrido grupo de topónimos carranzanos: La Lastra y Las Lastras, La Lastriega, Las Lastrillas, Las Lastrias, y en compuestos como Cerrolastrías, Vaolalastra y otros (con numerosas variantes que ahora no es cuestión el señalar). En el habla de todo el occidente vizcaíno se emplea con el sentido que figura en el DRAE (s.v.), 'lancha', 'piedra naturalmente lisa, plana y de poco grueso'. Su origen es incierto, quizá prerromano, aunque Corominas lo considera probable préstamo de los constructores de iglesias traído de Italia (italiano lastra 'baldosa'), donde sería derivado regresivo de LAȘTRICARE 'pavimentar' (de LASTRICO 'pavimento'). Por su parte, Hubschmid y Frago Gracia se muestran más partidarios de una base prerromana, muy posiblemente preindoeuropea, común a la Península

60 Lastra es corriente en el léxico y en la toponimia montañeses (cf. R. J. PENNY, op. cit., p. 295); en los asturianos, con variantes llastra y tsastra (cf. J. NeIRA y M. R. PIÑEIRO, op. cit., p. 210); en León se emplean las variantes llastra (F. RUBIO ÁlvAREZ, "Vocabulario dialectal del Valle Gordo (León)", RDTP, XII [1961], p. 298), chastra y lastra (A. R. FERNÁNDEZ GONZÁlez, Los Argüellos (León). Léxico rural y toponimia [Santander, 1966], pp. 158 y 171); lastra también se encuentra en el léxico y la toponimia alaveses (cf. G. LÓPEZ DE GUEREÑU, "Voces...”, cit., p. 275, etc.); y en las hablas rurales de Burgos y su toponimia (cf. F. GonZÁlez Ollé, "El habla de Quintanillabón", RDTP, IX [1953], p. 47; “Características fonéticas...", cit., p. 79; J. PÉREZ Carmona, op. cit., p. 264, etc.). En el Diccionario de Madoz (op. cit.) figuran Lastra y Lastrilla hasta las provincias de Segovia y Ávila, que parecen su límite meridional; para la presencia de este vocablo en el habla segoviana, cf. G. M. VERGARA y MARTín, Materiales para la formación de un vocabulario de palabras usadas en Segovia y su provincia (Madrid: Sucesores de Hernando, 1921), p. 50; y en Ávila, E. TEJERO RoBleDo, Toponimia de Ávila (Ávila: Institución "Gran Duque de Alba", 1983), p. 143. Asimismo se conoce esta voz en Soria (G. MANRIQue, "Vocabulario popular de la provincia de Sorian, RDTP, XXI [1965], p. 401), por donde el área castellana enlaza con la aragonesa (cf. G. RoHLFs, Diccionario dialectal del Pirineo aragonés [Zaragoza: Institución "Fernando el Católico", 1985], pp. 182-3; J. A. FRAGO, "Toponimia navarroaragonesa del Ebro (V)": yermos y pastizales", Archivo de Filología Aragonesa, XXXVIII [1986], pp. 106-7). 
Ibérica y a la Itálica, habida cuenta de que los testimonios medievales, y ya en la toponimia, son muy numerosos y antiguos ${ }^{61}$.

Más frecuentes $\mathrm{y}$, tal vez, característicos, son los testimonios de voces pertenecientes a un acervo léxico que denominaremos imprecisamente "Occidental", porque llega a veces hasta Galicia y carece de representación en Aragón y Navarra:

En La Argañeda (monte y arroyo), tenemos el colectivo de argaña 'hierba mala' (DRAE, s.v.), voz de origen desconocido, probablemente prerromano ${ }^{62}$, registrada en Asturias, región leonesa y Cantabria, y más esporádicamente en otros puntos del occidente peninsular, hasta enlazar con el gallego argana: hay Arganosa y Argañosa en La Coruña, Argañosos en Asturias, Argañoso en León y Argañin en Zamora ${ }^{63}$. En Cantabria, donde argaña presenta la acepción 'hierba alta' ${ }^{64}$, hallamos los topónimos $L a$ Argañosa y Argañal. El DCECH ofrece un primer testimonio de esta voz, con la forma argaña, del primer cuarto del siglo xIV, que puede ser adelantado al año 1068, fecha del diploma santoñés titulado "Donación o reja de Laredo", donde se lee: "Et una serna ubi dicunt in arganna" ${ }^{65}$.

${ }^{61}$ Cf. J. Hubschmid, "Lenguas prerromanas no indoeuropeas. Testimonios románicos", Enciclopedia Lingüística Hispánica, vol. I, pp. 46-7; J. A. FraGO, op. cit., pp. 106-7. El propio Corominas reconoce la importancia de la objeción apuntada: "La dificultad estriba en que en España los ejemplos antiguos no se refieren a la construcción, sino que aparecen como denominaciones topográficas" (DCECH, s.v.). La 1. ${ }^{\circ}$ documentación que ofrece el $D C E C H$ es "Ad Lastras", de un diploma emilianense del año 853 que parece el fundacional de San Martín de Flabio, en Losa (Burgos), donde también leemos "...usque ad illa barga qui sumat ad Lastra: alia serna sub Lastras..." (J. A. LLORENTE, Noticias históricas de las tres Provincias Vascongadas [Madrid: Imprenta Real, 1806-1808], vol. III, p. 81).

62 Cf. DCECH, s.v. argaña o argaya; J. HuBsCHMID, "Lenguas prerromanas no indoeuropeas..., cit., pp. 63-64.

63 Además, en bable, argañosu se aplica a 'todo terreno escabroso, produzca o no argaña' (cf. J. NeIRA y M. R. PIÑEIRO, op. cit., p. 47); en la toponimia menor asturiana abundan los testimonios de nombres de esta familia: cf. X. Ll. GARCía ARIAS, "De toponimia tebergana (III). Fitotoponimia", Boletín del Instituto de Estudios Asturianos, XCIX (1980), pp. 160-161 y A. M. CANO GONZÁleZ, "Nomes de llugar en Somiedo (Parroquia de Veigas). I. Fitotoponimian, Lletres Asturianes, XXIII (1987), p. 74, quienes recogen varios L'arganal, L'arganosa; M. A. ARIAs (op. cit., p. 249), Argañón y otros, todos ellos montes, como el nuestro. En León hallamos la voz argañal 'monte espeso de matorrales' y los topónimos El Argañal, Los Argañales y L'arganosa; cf. F. RuBio ÁllvareZ, op. cit., p. 273 y "Toponimia menor del Valle Gordo", RDTP, XX (1964), p. 87; A. R. FERNÁNDEZ GONZÁleZ, op. cit., p. 142.

gú M. A. Sálz Barrio, op. cit., p. 28.

65 M. Serrano SANZ, "Cartulario de la Iglesia de Santa María del Puerto (Santona), Boletín de la Real Academia de la Historia, LXXIII (1918), pp. 420-442; LXXIV (1919), pp. 19-34, 224-242 y 439-455; LXXV (1920), pp. 323-348. 
Por otra parte, el léxico topográfico de origen latino manifiesta a veces similares conexiones occidentales, y así se ve en la toponimia de otero 'cerro aislado' ( $D R A E$, s.v.), que en Carranza está representado por $E l$ Otero, con las variantes Lotero y El Lotero, Lutero y El Lutero ${ }^{66}$; y el derivado El Oterón, Loterón o El Loterón. Menéndez Pidal vio que los descendientes del latín ALTARIUM en la toponimia peninsular son característicos de su zona occidental, especialmente arraigados en Galicia, León y Zamora, desde donde parecen haberse difundido por Asturias, Salamanca y parte del centro de Castilla, además de en Portugal ${ }^{67}$. Los testimonios medievales de la voz, que no parece usada en Navarra ni Aragón, son muy abundantes en el reino leonés, con Portugal y Castilla ${ }^{68}$.

Como los derivados de ALTARIUM, otras voces evidencian cierta comunidad léxica primitiva entre los dialectos septentrionales y centro-occidentales de la Península hasta Vizcaya; sólo añadiremos el término luntria (La Fuente de La Luntria), variante regional de nutria, que alterna con lóndriga y lundre en las hablas montañesas; en los bables hallamos las

${ }_{66}$ Muestra ejemplar del falso análisis que afecta a este topónimo (fruto del desuso en el habla) es "...en La Llana delu Teru..." (AHPV 1722). La misma deformación de otero, con amalgama del artículo y cierre de vocal átona, se da en los zamoranos El Lutero y Teso del Lutero, recogidos por L. CORTÉs VÁzQuEZ, "Muestra de la toponimia menor zamorana", Philologica I. Homenaje a D. Antonio Llorente (Salamanca: Universidad de Salamanca, 1989), p. 224, quien los interpreta como derivados del latín LUTUM [?], explicación inaceptable en cuanto a la fonética histórica. Hay otro Lutero en Burgos; cf. G. MARTÍNEZ DÍEZ, "Toponimia mayor y repoblación en la provincia de Burgos", Actas de la Reunión Científica sobre toponimia de Castilla y León (Burgos: Caja de Burgos, Aula Universitaria de Filología e Historia, 1994), p. 45.

67 "Forma así un área continua al Noroeste de la Península, cuyo límite lo marcan los dos Otero del Sudeste de Santander, el Oteruelo de Logroño, Oteruelos de Soria, Oter de Guadalajara, Los Oteros de Cuenca, El Otero de Toledo, Oteruelo de Salamanca, y los abundantes Outeiro, Outeirinbo, Outeiral, Outeirão, etc. que existen por todo el Sur de Portugal" (R. MenÉNDEZ PIDAL, Origenes del español [Madrid: Espasa-Calpe, 1980] [9. ${ }^{a}$ ed. según la 3. ${ }^{a}$ muy corregida y adicionada], p. 408).

68 De Burgos procede la que podría ser la forma documentada más antigua: Uter de Alios, 1068 (R. MENÉNDEZ PIDAL, Orígenes..., cit., pp. 98-100); hay otras formas semilatinas, como autarium, en un diploma asturiano de 879 (A. C. FLORIANO, op. cit., vol. II, p. 760). En cuanto a los ejemplos más orientales del latín ALTARIUM, próximos a nuestra comarca, además de algunos burgaleses (J. Pérez Carmona, op. cit., p. 257), en Álava tenemos $\mathrm{El}$ Otero, El Otero Ancho, Los Oteros, aunque en esta zona no abunda, como señala M. N. SÁNCHEZ GONZÁlez DE HERRERO, El habla y la toponimia de la Puebla de Arganzón y el Condado de Treviño (Vitoria: Diputación de Álava, 1986), p. 203. Otros derivados de ALTARIUM en la toponimia castellana son examinados por A. LLORENTE MALDONADO DE GUEVARA, Los topónimos españoles y su significado (Salamanca: Universidad de Salamanca, 1991), p. 45. 
formas llondria, llondru, llontria, llóntriga, londra, con otras variantes fonéticas ${ }^{69}$. Las diversas formas romances derivan de otras tantas adaptaciones de la voz griega al latín provincial: NUNTRA > LUNTRA O LUNDRA, según el $D C E C H$ (s.v.), que indica, además, que luntria también se conoce en portugués.

Siguiendo con los occidentalismos, debemos detenernos a señalar algunos hechos fonéticos lexicalizados aunque frecuentes, como el mantenimiento de -MB- latino, tenido por no castellano, que se encuentra en $L a$ Cambera 'camino carretil', La Lomba, El Lombo, La Lombilla ${ }^{70}$, Los Lombanos, Lombera, El Palombar, Palombera y otros. Vinculan nuestra zona con un área fonética occidental y cantábrica, gallego-portuguesa, asturleonesa y montañesa ${ }^{71}$.

Análogamente, enlazan con lo leonés los ejemplos de palatalización de L- en la familia de lama: Las Llamas, La Llamosa, Las Llamosillas o Llamosias, Llamarales y Llamazares; y en los derivados del latín LACUS o LACUNA: La Llaguna, Las Lagunas o Llagunas, Llaguno, El Llago o Llao y Los Llaos. Estas formas enriquecen la arqueología de lo que en otro tiempo fue también tendencia castellana no generalizada, pues, como pudo ver Pidal, "al este de la ciudad de Santander, aunque no tengamos residuos léxicos, la palatalidad fue general, como lo indica la toponimian, cuyos ejem-

69 M. Á. Saiz Barrio, op. cit., pp. 157-158; J. Neira y M. R. Piñeiro, op. cit., p. 250.

70 En Carranza se emplea lombillo o lombio con la acepción de 'montoncillo de hierba para su secado'; en este sentido, lombillo equivale a cambada, que también se emplea. Con una acepción similar encontramos lombillo y su variante lombio en las hablas montañesas; cf. A. GARCíA LOMAS, op. cit., p. 224; A. LÓPEZ VAQUE, Vocabulario de Cantabria (Santander, 1988), p. 191; M. Á. SÁlZ BARrio, op. cit., p. 157.

71 Pero sin olvidar que también en Álava, Rioja y Navarra los derivados de LUMBU suelen conservar este grupo. En La Rioja se conocen lomba y lombado 'alomado' (C. GoICOECHEA, Vocabulario riojano [Madrid: RAE, anejo VI del BRAE, 1961], p. 107); de Álava, LÓPEZ DE GUEREÑ (Voces..., cit., pp. 184 y 277) recoge lomba y alombar referido a 'hacer surcos espaciados en la tierra', y, en los topónimos Loma y Lomba, Lombano (a. 1697), Lombecogana (a. 1607), Lombilla y Traslomillo; también son alaveses La Lomba de Arceniega (I. HoRCH, Zur Toponymie des Valle de Mena / Castilla und des Valle de Ayala / Álava [Bonn: Universidad, 1992], p. 278) y los numerosos derivados de LUMBU que conservan -MB- en Treviño y Puebla de Araganzón (M. N SÁNCHEZ GONZÁleZ DE HERRERO, op. cit., pp. 57 y 201-202); en Navarra, lombada 'porción de tierra que deja el arado sin labrar' (Iribarren, op. cit., p. 320). Asimismo, en Aragón se dan casos de -MB- conservado en derivados de LUMBU, tal vez en relación con el antiguo mozarabismo de parte del Aragón Medio y de la Navarra ribereña, según Frago Gracia (Toponimia del Campo de Borja. Estudio lexicológico [Zaragoza: Institución "Fernando el Católico", 1980], pp. 124-126; “Toponimia navarroaragonesa del Ebro (IV): orónimos", Archivo de Filología Aragonesa, XXX-XXXI [1982], pp. 41-42). 
plos llegan "hasta el extremo confín con Vizcaya" "2. Los testimonios toponímicos se hallan en otros puntos de Castilla la Vieja, los cuales suman al occidente de Vizcaya: nuestra comarca, de la que Pidal conocía los topónimos Llaguno (Trucíos) y Las Llamas (Carranza), pues figuran en Madoz (op. cit.), y se unen a la región santanderina "señalándonos todo el norte de Castilla como región donde la $l$-palatal debió desaparecer bastante tarde cuando persiste en tanto nombre de lugar ${ }^{73}$. De este modo, la palatalización de L- es rasgo diacrítico que indica una diferenciación interna en la geografía del castellano: el español no presenta palatalización, frente a una palatalización original del castellano más norteño.

\subsubsection{Regionalismos castellanos norteños específicos}

Son más numerosos y significativos los regionalismos propios de un área mejor definida, comunes con Cantabria y el norte de Castilla, que a menudo llegan a Asturias, y por oriente, a Álava y La Rioja. Unas veces es la acepción semántica que origina el topónimo la que el español general desconoce; otras, el regionalismo afecta a toda la palabra; y, en ocasiones, descubrimos una variante fonética regional de una voz que tiene otra forma en otros lugares.

Por ejemplo, los diccionarios generales del idioma no se hacen eco de la acepción orográfica con la que mazo y maza se usan, no sólo en Carranza, sino también en Burgos y Cantabria ${ }^{74}$. Son carranzanos La Maza,

72 Cf. R. MENÉNDEZ PIDAL, "Dos problemas iniciales relativos a los romances hispánicos", Enciclopedia Lingüística Hispánica, vol. I, pp. XCV y ss.

73 Y a los conocidos por Pidal, aún pueden añadirse nuevos ejemplos de la toponimia menesa (norte de Burgos) como Llomo (J. Bustamante BRICIO, Toponimia menesa [Bilbao: Real Sociedad Vascongada de Amigos del País, 1982], p. 317), Llaguio, Llamares (I. HORCH, op. cit., pp. 79-82). En fin, con respecto al área original del fenómeno, Pidal señala que, frente a la Castella Vetula primitiva (hoy partido de Villarcayo, vecindades de Encartaciones de Vizcaya y provincia de Santander), lo mismo que León y Asturias (con Cataluña y los mozárabes), sólo Burgos, la cabeza del nuevo gran condado de Castilla del siglo $\mathrm{X}$, se mostró refractario a la palatalización inicial: "El poderoso influjo de Castilla hizo que la palatal $l l$ - fuese relegada en los dialectos de Santander, de León y de Aragón afines al castellano, y que desapareciera modernamente en Salamanca" (Dos problemas...", cit., p. CXXXVI). Cf. además V. GARCíA DE DIEGo, Manual de dialectología española (Madrid: Centro Iberoamericano de Cooperación, 1978) (3." ed.), p. 36 y R. LAPESA, Historia de la lengua española (Madrid: Gredos, 1981) (9." ed. corregida y aumentada), p. 178, con algunos ejemplos más.

74 Según el DRAE, maza, "arma antigua, hecha de palo guarnecido de hierro, o toda de hierro, con la cabeza gruesa", tiene varios sentidos más, pero ninguno aplicable a la 
con o sin especificaciones (como en La Maza de Los Frailes o La Maza Redonda), y también como término de referencia (Fuentelamaza, Zorrolamaza o Zorralamaza, etc), con los derivados La Mazuela, La Mazuca y Las Mazucas. Además, encontramos el masculino El Mazo (término de referencia en El Castañal del Mazo, La Fuente del Mazo, La Loma del Mazo o La Peña del Mazo). El DCECH (s.v. maza) ofrece un primer testimonio literario del siglo XIV (Juan Manuel y Juan Ruiz, entre otros), de los valores 'arma', 'martillo' que se encuentran en el $D R A E$ y en Autoridades $^{75}$, pero existe una documentación montañesa del año 1047: "...et usque ad lako de Flarines, et per illa macca..." ${ }^{76}$, con valor toponímico idéntico al que comentamos. En la encuesta se describió mazo como 'pico de piedra', y el mismo sentido se registra en el habla de otros lugares de Las Encartaciones ${ }^{77}$; en Burgos, maza 'cumbre de algunas montañas' ${ }^{78}$; y en Cantabria, 'monte rocoso' 79; una aldea de Llanes (Asturias), El Mazucu, tiene estas mismas características. Así pues, parece claro que puede hablarse de una acepción orográfica de maza y mazo en el habla de las comarcas cantábricas, con núcleo montañés y estribaciones burgalesa y vizcaína.

Dentro del grupo de los particularismos léxicos que consideramos castellanos norteños, incluimos los formados por El Borto, Cuestalborto, Salborto o los varios El Bortal, que surgen de las denominaciones borto 'madroño', borta 'fruto del madroño', y bortal 'bosque poblado de bortos', usuales hoy al menos en Carranza y en el vecino Trucíos ${ }^{80}$. Borto y bortal,

descripción del terreno. En cuanto a mazo, derivado del femenino, en el DRAE (s.v.) figura como acepción principal la de 'martillo grande', sentido que procede del latín vulgar *MATTEA, al parecer, derivado retrógrado del latín MATEOLA.

75 Idénticas acepciones en los testimonios medievales de M. ALONSO, op. cit., vol. II, pp. 1.364 y 1.370 .

76 Es la llamada "Reja de Escalante" (M. SERrano SANZ, op. cit., 1918, p. 432); en la "Pesquisa de los bienes que pertenecieron a Santa María del Puerto", de 1210, "...una tierra ena maza..." (M. SERRANO SANZ, op. cit., 1920, p. 343).

77 En Trucíos hallamos mazo 'promontorio rocoso y escarpado' y los topónimos El Mazo (2 veces), La Maza, La Mazuca y La Mazuela (cf. J. M. SAlBideGoitiA, "Estudio etnográfico del Valle de Trucíos (Vizcaya),, Kobie, X [1980], pp. 155 y 160); además hay El Mazo en Zalla.

78 Cf. J. DE LA CRuZ MarTíneZ, "Algunas voces de Hornillayuso (Burgos)", RDTP, XVII (1961), p. 559; J. Bustamante Bricio, op. cit., p. 307.

79 "De muy antiguo se ha designado por la parte oriental de Cantabria con el nombre de mazas a unas alturitas situadas especialmente en las mieses y llanadas de los pueblos y que, al parecer, no tienen prestancia para llegar a cuetos. [...] Con la palabra Mazo pasa lo mismo de aplicarse al sitio de su ubicación" (F. Sojo y LOMBA, ¿De Re...", cit., pp. 612-614, con numerosísimos ejemplos toponímicos).

80 Cf. J. M. Salbidegoitia, op. cit., p. 154. 
con los sentidos mencionados, figuran en el DRAE como voces propias de Álava, Burgos y Logroño; y según el DCECH (s.v.) son alavesas, riojanas y también vizcaínas ${ }^{81}$. Ciertamente, el área de esta voz debe ampliarse a Vizcaya, pues así lo justifica su difusión en la toponimia de Las Encartaciones: El Bortal en Galdames; Bortal de Aguirza en Güeñes; Bortal de La Lobera en Gordejuela y La Bortosa en Trucíos. Por otra parte, ni el $D R A E$ ni el $D C E C H$ registran borto (aunque sí sus variantes el $D C E C H$ ) en Cantabria, donde existe junto a aborto, alborto, algorto, y aborio; y bortal al lado de bortedo, abortal y albortal 82 .

Los topónimos La Cayuela o Las Cayuelas, con derivados como La Cayelosa o Cayuelosa, El Cayuelón y La Cayueluca, dan testimonio de la voz cayuela, que goza de pleno uso en el habla de Carranza ${ }^{83}$; el DRAE la define como aroca caliza de color azulado, que abunda en fósiles del período cretáceo", y la localiza en Álava y Santander ${ }^{84}$. Pero se emplea también en otros lugares, fundamentalmente en el habla de Las Encartaciones vizcaínas, comarca que conecta Álava con Cantabria, y desde donde, seguramente, cayuela 'roca estratificada' ha penetrado en el habla de

81 El $D C E C H$ (s.v.) olvida la localización burgalesa que sí se encuentra en el $D R A E$ (s.v.); dentro de la provincia, esta voz se ha recogido en Mena (F. GonZÁlez Ollé, "Características fonéticas...", cit., p. 74), en cuya toponimia hallamos Bortedo (J. Bustamante Bricio, op. cit., p. 296), Bortal y La Bortosa (I. HORCH, op. cit., pp. 190-191).

82 Cf. V. García DE DIEGO, "El castellano como complejo dialectal y sus dialectos internos", $R F E$, XXXIV (1950), p. 116; A. García LOMAS, op. cit., p. 54; A. LÓPEZ VAQue, op. cit., pp. 57-58; M. A. SÁrz BarRiO, op. cit., pp. 12 y 45, etc.; J. P. Sánchez Llamosas (op. cit., pp. 34, 58-59) recoge también borta 'fruto del madroño', voz ausente de los demás vocabularios, aunque la registró el padre Terreros (Diccionario castellano con las voces de las ciencias y artes [Madrid: Arco, 1987] [ed. facsímil de la primera, de 1788], s.v. madroño) como propia de las Montañas de Burgos.

83 Damos el ejemplo de su empleo espontáneo en la definición de lastra en algunos informes de nuestras encuestas: "un trozo de cayuela grande, que hace pendiente"; "una cayuela resbaladiza"; también designa la piedra de los ríos. Disponemos también de varios testimonios documentales: a... embutiendo lo necesario de cada una en la cayuela o cascajo que se halla en dicho sitio.... (AHPV 1753, sobre la reparación del puente de El Callejo); “... y por la parte de la peña o cayuela que se halla en dicho sitio..." (AHPV 1752).

84 En Álava, cayuela 'roca caliza azulada dispuesta en capas'; cf. F. BARÁIBAR, Vocabulario de voces usadas en Álava (Madrid: Establecimiento tipográfico de Jaime Ratés, 1903), p. 72; G. LÓPEZ de GuEREÑU, Voces..., cit., p. 222; es topónimo de Ayala (F. BARRENENGOA, op. cit., vol. III, p. 151). En las hablas montañesas, designa ciertas "rocas en capas o estratos de espesor variable que se descomponen fácilmente en hojas o placas, como las margas, las limonitas y las pizarras" (M. A. SÁlz BARRIO, op. cit., p. 65; cf. A. García lomas, op. cit., p. 110, etc.). 
Bilbao. Además; esta voz está presente en la toponimia burgalesa y se encuentra en la zona oriental de Asturias con el sentido 'barro' ${ }^{85}$.

La Llosa es topónimo muy común, con derivados de interés, como $\mathrm{La}$ Llosia, Las Llosias o Llusías, La Llosuca y Las Llosucas, y que forma una muy larga serie de nombres compuestos, pues es voz usual aún, con el sentido general 'terreno labrantío', aunque las llosas como tales corresponden a otra época de la producción agrícola. El DRAE (s.v.) localiza llosa en Asturias, Santander y Vizcaya, y, por lo que se refiere a la última, hemos de precisar que corresponde al romance de Las Encartaciones, sobre todo a la zona más occidental de la comarca (Trucíos, Carranza y Lanestosa) ${ }^{86}$. Su significado, que el DRAE (s.v.) describe como "terreno labrantío cercado, mucho menos extenso que el de las mieses, agros o erías, y por lo común próximo a la casa o barriada a que pertenece", deriva metonímicamente del etimológico: del bajo latín (CORTE) CLAUSA '(posesión) cerrada o cercada', que figura en los diplomas medievales con las formas gráficas plosa (1084) y losa (1163) ${ }^{87}$. Resto del sentido original del término sobrevive en su descripción, pues siempre se indica que las llosas "estaban cerradas todas en común", es decir, que incluía propiedades de todos los vecinos ${ }^{88}$. Indicios toponímicos muestran que la geografía de esta voz, la

85 De Bilbao, cf. E. DE ARRIAGA, Lexicón etimológico, naturalista y popular del bilbaino neto (Madrid: Minotauro, 1960), (2." ed. aumentada) p. 60; de Burgos, B. OsABA y Ruiz DE ERENChun, op. cit., p. 56; I. HorCh, op. cit., p. 210; del oriente asturiano, S. BLANCO PIÑán, "Adiciones al vocabulario asturiano de la parroquia de Meré (Llanes)", Boletín del Instituto de Estudios Asturianos, LXXV (1972), p. 104. En cuanto a su etimología, el $D C E C H$ (s.v. calle) sólo le dedica una línea: “el santanderino cayuela [...] quizá no venga de escayola, pero desde luego no tiene relación con caillou ".

86 En las hablas montañesas, se registra esta voz con idéntico valor (A. GARCía LOMAS, op. cit., p. 227; M. A. SÁIZ BARRIO, op. cit., p. 160, etc.), y su toponimia es extraordinariamente abundante en la región. En Asturias conoce el mismo significado, con variantes comarcales como llosa, yosa, tsosa, llousa, tsousa, y otras (cf. J. NeIRA y M. R. PIÑEIRO, op. cit., p. 217), que se reflejan en la también abundante toponimia menor; cf. S. BLANCO PIÑÁN, "Vocabulario toponímico de la parroquia de Meré (Llanes)", Boletín del Instituto de Estudios Asturianos, LXXIV (1971), pp. 567-568; X. Ll. GarCía ARIAS, "De toponimia tebergana (V). La organización del espacio agrario", Boletín del Instituto de Estudios Asturianos, CV-CVI (1982), pp. 431-432.

87 Cf. DCECH, s.v. llosa; otros ejemplos, todos del cartulario de Santillana, son flausa (1034) y flosa, del siglo XII (MENÉNDEZ PIDAL, Orígenes..., cit., pp. 238-9). En la documentación primitiva del reino asturiano son corrientes los términos clausa, clusa, conclusa y lausa (listas de ejemplos en A. C. FloRiano, op. cit., vol. I, p. 602 y vol. II, pp. 735-736); un diploma del año 861 referido a Piasca (Cantabria) recoge la venta de una la viña que está "in illa clausa", y que venden "cum sua clausura" (apud A. C. Floriano, op. cit., vol. I, p. 314).

88 En las Ordenanzas Municipales de 1855 se decía al respecto lo siguiente: "Las llosas o mieses comunes permanecerán cerradas constantemente", disposición que 
cual abarca desde el occidente de Vizcaya hasta Asturias, habrá de ampliarse al norte de Burgos y a Álava, a juzgar por su toponimia ${ }^{89}$.

El Ameyadero, con las variantes El Meadero y El Miadero, atestigua otra palabra de difusión regional y aún viva: ameyadero 'lugar en que sestean los ganados', 'sesteadero' deriva del verbo ameyar 'sestear los ganados a la sombra'. Las hablas montañesas conocen el verbo amellar o amillar, "guarecerse los animales del sol y la lluvia", variantes de mediar, midiar, miyar o miar, "sestear el ganado al mediodía" ${ }^{90}$. También en los bables se registra miyar, "dormir las ovejas reunidas a la sombra", y michar, "situarse el ganado vacuno en época de calor en sitios elevados donde corre el viento" ${ }^{11}$.

Y el topónimo carranzano Las Quimas documenta la voz quima 'rama', 'rama especialmente gruesa', corriente en el habla de la comarca, y que figura en el $D R A E$ como propia de Asturias y Santander ${ }^{92}$; el $D C E C H$ (s.v.

tenía carácter obligatorio, y cuya infracción era castigada (M. LÓPEz GIL, op. cit., p. 41). La historia de la llosa en estas tierras se relaciona con la de la producción de cereales; cf. J. A. García de Cortázar, B. ARizaga et alii, op. cit., vol. II, pp. 19-20; y para Cantabria, J. A. GARCía DE CoRTÁZAR y C. DíEz HerRera, La formación de la sociedad bispano-cristiana del Cantábrico al Ebro en los siglos VIII a XI (Santander: Estudio, 1982), pp. 165-166.

89 En Álava hallamos La Llosa y La Lloza, Villallosa. La Llosa y Llosa Vieja son de Mena (I. HORCH, op. cit., p. 277; J. Bustamante BRICIO, op. cit., p. 317), y hay La Llosa en el partido judicial de Villarcayo.

90 J. P. SÁnChez llamosas, op. cit., p. 37; M. A. SÁIZ Barrio, op. cit., pp. 21, 168, 170, 171; en el habla pasiega, encontramos miyar y miaderu (R. J. PENNY, op. cit., p. 244); Los Miaderos, "lugar de reposo de los ganados", es topónimo del vecino valle de Soba (M. A. SÁrz ANTOMil, "Aportación a la topología del valle de Soba", Altamira, XII [1956], p. 249).

91 X. Ll. GARCíA ARIAS, "De toponimia tebergana (III). Fitotoponimia", Boletín del Instituto de Estudios Asturianos, XCIX (1980), p. 175; aunque García Arias piensa que "nos encontramos ante derivados de miriare con un sentido de sestear al medio día", parece más sencillo recurrir a *MEDIARE, de MERIDIARE, con -DJ- que ha originado la palatal de las formas romances. La pérdida de $y$ tras vocal palatal en miyadero > miadero / meadero es el mismo fenómeno que se ve en -ia,-io por -illa,-illo (cf. I. ECHEVARRía IsUSQUiza, "Una contribución vizcaína a la historia del yeísmo español", Actas del IV Congreso Internacional de Historia de la Lengua Española (La Rioja, 1997); en prensa). Recuérdese que si MEDIUs hubiese sufrido una evolución fonética espontánea, el resultado habría sido meo, a través de una fase meyo que fue sustituido por medio (DCECH, s.v. medio); aún se aprecia en el navarro meano 'mediano' (J.M. IRIBARREN, op. cit., p. 342).

${ }^{2}$ Quima y derivados son habituales en las hablas montañesas (cf. J. P. SÁNCHEZ LlAMOSAS, op. cit., p. 174, quien también señala que quima "se oye mucho en Las Encartaciones»); García Lomas recoge las variantes quimba, quilma y quima, con los 
esquilmar) amplía su geografía a Las Encartaciones vizcaínas. Pero, además, se conoce en Ayala, Álava; por otra parte, kima 'punta de las ramas' se registra en el euskera vizcaíno y, como 'renuevo de la col' en el de la Navarra francesa ${ }^{93}$.

Entre los regionalismos fonéticos destacamos La Herrán ${ }^{94}$, variante de herrén 'forraje' y 'terreno en que se siembra' (DRAE, s.v.), que corresponde a los ferragines o herrenales de la documentación medieval ${ }^{95}$. Herrán procede del latín vulgar FERRAGO, -AGINIS, que, al igual que sus descendientes medievales románicos, es palabra femenina; el género masculino moderno, ya en Autoridades, obedece a la tendencia general que el castellano muestra con las palabras en én (vid. DCECH, s.v. herrén). La variante herrán registrada en la toponimia de Carranza es bastante común en los diplomas medievales ${ }^{96}$, pero FERRAGINE ha dejado una variada

aumentativos quimbón y quimbal (op. cit., p. 289). En Asturias parece sólo voz propia de la zona oriental (cf. J. NeIRA y M. R. PIÑEIRo, op. cit., p. 289).

93 El dato alavés lo proporciona F. DE BARRENENGOA, op. cit., vol. I, p. 45, y cf. $D C E C H$, s.v. esquilmar. Procede del latín vulgar QUIMA 'brote, vástago tierno', de origen griego; Berceo utiliza cima con el significado de 'rama de árbol' en algunas de sus obras. Para el derivado medieval esquimar, variante esquilmar, cf. también J. Corominas, op. cit., vol. I, pp. 362-364.

94 La Herrán o Larrán, dos lugares en Carranza y varias ocurrencias como término de referencia (La Cuesta de La Herrán, El Puente de La Herrán), y, posiblemente, Los Jarranes (en Soscaño), plural de berrán / jerrán, con apertura de átona ante vibrante múltiple y cambio de género.

95 Prados de aprovechamiento individual, situados en las zonas más regadas, y que, frecuentemente, compartían con los huertos el alvéolo que rodeaba las casas. Su función básica era proporcionar hierba fresca y heno para el ganado estabulado durante los meses de invierno, pero, a menudo, se plantaban en ellos árboles frutales (R. MARTÍnez OCHOA, "La ordenación del territorio en la más vieja Castilla en los siglos IX a XI", Boletín de la Institución "Fernán González", CLXXXIX (1977), p. 334). J. Á. García de Cortázar se fija en el papel que tuvo la ferragine en el proceso de concentración del poblamiento entre el x y el xl, época en que muchas de éstas comienzan a desaparecer, transformadas en solares destinados a la edificación; cf. J. Á. GARCía DE CORTÁZAR, "La organización del territorio en la formación de Álava y Vizcaya en los siglos VIII a fines del IX", en VVAA, El hábitat en la historia de Euskadi (Bilbao: Colegio de Arquitectos Vasco-Navarro, 1981), p. 153.

96 Encontramos berrán en un documento riojano de 1242 (R. MENÉNDEZ PIDAL, Origenes..., cit., p. 224) y ferrán en otro leonés de 1250 (DCECH, s.v.). La a tónica sin inflexión en berrán, sartán y otros, se debe a que el AI formado por pérdida de consonante intervocálica, está más retrasado en su evolución que -ARIU; conserva aún la vocal $a$ hasta el siglo XII, y el diptongo $a i$, $e i$ se ve en Castilla y Aragón durante el período de orígenes y aun en los siguientes (cf. R. MENÉNDEZ PIDAL, Orígenes..., cit., pp. $78-79$, n. 1 y 81 ). 
descendencia en las comarcas castellanas, como señaló García de Diego: "El latín ferragine tiene una zona vasca de larrain y arrain con la forma rain, en Álava [...] y la forma herrain que desciende por la Sierra de la Demanda hasta Duruelo, de Soria; están mal precisadas las zonas de raña, de herraña, de herreña y la de berrén ${ }^{97}$. En cuanto a la forma herrán, apreciamos que se ve también en Álava, en cuya toponimia hallamos numerosos Herrán y Herranes; y en Cantabria, donde se conocen las formas berrán y jerrán, "tierra dedicada al cultivo de productos para forraje del ganado" ${ }^{98}$, con varios Herrán en la toponimia. Asimismo, son análogos a los nuestros los meneses El Errán, La Herrán y Las Herranes ${ }^{99}$. Con estos datos podemos señalar que el norte de Burgos, parte de Álava (Ayala, fundamentalmente), el occidente vizcaíno y Cantabria forman el área compacta de berrán, variante que permite así trazar una subárea castellana norteña bastante clara.

Además, en lo fonético, no podemos dejar de señalar que la intensa variación de las formas toponímicas registradas refleja algunas tendencias no lexicalizadas:

Los topónimos carranzanos exhiben una gran inestabilidad en el timbre de las intertónicas, rasgo característico de la pronunciación vulgar o

97 "El castellano como complejo...", cit., p. 109. De las formas señaladas por García de Diego, podemos decir que herrén se registra además en Álava y su toponimia, donde convive con otras variantes (cf. M. N. SÁNCHEZ GONZÁlEZ DE HERRERO, op. cit., pp. 267-268); en Tierra de Campos (S. García Bermejo, "Contribución al vocabulario de la Tierra de Campos", RDTP, II [1946], p. 480), y en otros puntos de Castilla: en Burgos también como harrenes (J. DE LA FUENTE CAMINALS, "Algunas palabras de Guadilla de Villamar, provincia de Burgos", RDTP, V [1949], p. 149). La variante ren es riojana (C. GoICOECHEA, op. cit., p. 146) y salmantina (P. SÁnCHEZ SEvilla, "El habla de Cespedosa de Tormes (en el límite de Salamanca y Ávila)", RFE, XV [1928], p. 269); en Guadalajara encontramos renes, además de la palatalización arreñal (G. M. VERGARA Y MARTíN, "Algunas palabras de uso corriente en la provincia de Guadalajara que no se hallan en los diccionarios", $R D T P$, II [1946], pp. 144 y 135), que también se ve en Cuenca (P. JUNTA MarTíneZ, "Voces de Castejón (Cuenca), RDTP, XVIII [1962], p. 529); otras formas con palatalización son las riojanas herraña, herrañe y arrañal (J. MAGAÑa, "Contribución al estudio lingüístico del Vocabulario de la Riojan, RDTP, IV [1948], p. 272; C. GOICOECHEA, op. cit., pp. 99 y 30); harreñal, harrañes, herrañes son sorianas (C. MANRIQUE, "Vocabulario popular comparado de los valles del Duero y del Ebro", RDTP, XII [1956], p. 29); harrañal, harreñal, herrañal, rañal, reñal se hallan Zamora (A. ÁLVAREZ TEJEDOR, Estudio lingüístico del léxico rural de la zona este de la provincia de Zamora [Salamanca: Universidad de Salamanca y Colegio Universitario de Zamora,1989], p. 43), donde también se conoce ferraña (M. MOlinero LozANO, "Algunas voces de Zamora", RDTP, XVII [1961], p. 552).

98 Cf. V. Renero, "Formas dialectales y toponímicas de Cantabria", Altamira, I-III (1947), pp. 250; M. Á. SÁIz BARRIO, op. cit., pp. 140 y 148.

99 J. Bustamante Bricio, op. cit., p. 315; I. Horch, op. cit., p. 251. 
dialectal, posiblemente porque éste ha sido uno de los aspectos en que la norma idiomática se ha mostrado más remisa y lenta ${ }^{100}$. La vacilación registrada en los siguientes muestra la tendencia al cierre: La Arenilla / La Arinilla, El Barbechuelo / El Barbichuelo, Campollano / Campullano, El Chorretón / El Cburretón, El Helguero / El Hilguero, El Jelguero / El Jilguero, La Fontanía / La Funtanía, Las Gandarias / Las Ganderias / Las Gandirias, La Gorguera / La Gurguera, La Josía / La Jusía, La Llosía / La Llusía, El Otero / Lutero, El Pomar / El Pumar, Pomarejo / Pumarejo, El Pontón / El Puntón, El Pozón / El Puzón, Soscaño / Suscaño, Vellanosa / Villanosa y otros muchos. La tendencia a la apertura es menos frecuente que al cierre y, en general, parece condicionada por contacto con vibrante múltiple, situación en sílaba trabada, etc.: El Herbal / El Harbal, Herbosa / Harbosa, Bustillo / Bostillo, Quebrantón / Cabrantón, El Cerrillo / El Zarrillo, La Jelechosa / La Jalechosa, El Risquero / El Rasquero, El Terrero / El Tarrero, etc. Aunque idénticas articulaciones antinormativas, propias del habla vulgar y rústica en general, se encuentran en otras hablas castellanas e hispánicas, deben destacarse los cuantiosos testimonios de las zonas vecinas a Carranza, principalmente del norte de Burgos y hablas montañesas ${ }^{101}$.

100 En el transcurso del siglo XVI, las vacilaciones de timbre en las vocales no acentuadas fueron disminuyendo, pero sin desaparecer (cf. R. LAPESA, op. cit., p. 368). La descripción articulatoria del fenómeno se encuentra en T. NAVARro TOMÁs, Manual de pronunciación española (Madrid: CSIC, 1980) (20." ed.), $₫ 44$; hay bibliografía general y dialectal en J. ALciNa y J. M. Blecua, Gramática española (Barcelona: Ariel, 1975), p. 290 y n. 72.

101 Para Bureba, cf. F. GonZÁlez Ollé, El habla de la Bureba (Madrid: CSIC, anejo LXXVIII de la RFE, 1964), p. 27; I. HORCH (op. cit., pp. 77 y ss.) registra el fenómeno en la toponimia menesa. Traen numerosos ejemplos montañeses A. GARCía LomAS, op. cit., pp. 37-40; F. GaRCía GonZÁleZ, "J. M. de Pereda y el dialecto montañés", Archivum, XXVII-XXVIII (1977-8), pp. 473-4; PENNY (op. cit., pp. 52 y ss.) ha descrito la tendencia pasiega (por la asimilación de las átonas a las tónicas) a un sistema de sólo tres vocales átonas, con $e$ e $i$ convertidas en alófonos de una misma vocal, realizada $e$ o $i$ según la tónica, y lo mismo ocurre con $o$ y $u$. J. A. Fernández considera en el bable de Villarín el mismo sistema de dos grados de abertura en las átonas compuesto por /a/ y dos archifonemas, uno palatal /I/ y otro velar /U/: "Si bien es cierto que el castellano de todas partes y de todas las épocas demuestra cierta inestabilidad en cuanto a timbre de las vocales inacentuadas, el bable va más allá y se manifiesta muy propenso a pronunciar, en el caso de /e, o/ átonas, la variante más cerrada, o sea /i,u/" ("Aportación al estudio del bable de occidente: el habla de Villarín (Salas)» I. Fonología y morfosintaxis", RDTP, XXXV [1979-80], p. 58). El fenómeno asturiano entronca con el gallego, donde la inestabilidad del vocalismo átono permite, aun a nivel idiolectal, variantes como pereira / pireira, pértega / pértiga, etc. (cf. A. SANTAmarina, "Problemas para la restauración de topónimos gallegos", Actas de las 
Típicamente, el habla carranzana tradicional cierra las vocales finales, $-o$ en $-u$ y $-e$ en $-i$, aunque el cambio de $-e$ en $-i$ es más raro. El cierre de la velar final puede observarse aún: es muy regular es en la pronunciación de los topónimos y caracteriza, sobre todo, a los hablantes ancianos y rústicos. Los vecinos son conscientes de este rasgo conocido, como "hablar con la $u$ ", que se siente como vulgarismo propio en la correspondencia con la forma general castellana -o. Este comportamiento de las átonas finales, descrito por Menéndez Pidal como leonés, goza aún hoy de amplitud y vitalidad en el área central del dialecto ${ }^{102}$. En Carranza y Encartaciones occidentales prolonga el área montañesa, modalidad dialectal que caracteriza ${ }^{103}$. No obstante, también es propio de las hablas del norte de Burgos, que se ligan así al occidente vizcaíno y a Cantabria ${ }^{104}$.

Una muy estrecha conexión con las hablas montañesas se ve en la huella de la aspiración de /F-/ latina, confundida con la pronunciación $\mathrm{de} / \mathrm{x} /{ }^{105}$. Los hablantes son conscientes de este rasgo ya caduco, que muestra ejemplos abundantes en el léxico y abundantísimos en la toponimia: por ejemplo, en los derivados del latín FAGEA, son muy numerosos La Jaya, La Jayuela, Las Jayas, El Jayal (aunque El Haya o La Haya sean corrientes) y el también colectivo El Jaido que contrasta con Haedo. En los derivados de FOVEA, son muchos los La Joya y El Joyo / El Juyo (recogidos como variantes de un mismo topónimo o designando lugares distintos) y muy significativas algunas expresiones redundantes

I Jornadas de Onomástica. Toponimia [Bilbao: Euskaltzaindia, 1991], p. 243). J. BorReGO Nieto ("Leonés", en M. ALVAR (dir.), Manual de dialectología bispánica. El español de España [Barcelona: Ariel, 1996], p. 151) incluye la vacilación con tendencia al cierre de la átonas no finales, entre los rasgos vocálicos no lexicalizados aún observables claramente en el límite oriental de los fenómenos constitutivos del leonés (que corresponde al leonés central de Pidal).

102 Cf. R. MENÉndez PIDAL, El dialecto leonés (Oviedo: Instituto de Estudios Asturianos, Diputación de Asturias, 1962), pp. 54 y ss.; J. BORREGO NiETO, ibid.

103 El cierre de finales es común a toda la Montaña, si bien no se encuentra con el mismo grado de intensidad e idéntica distribución en las distintas comarcas (cf. F. GarCía GonZÁleZ, op. cit., pp. 471-473); concretamente, en la comarca pasiega Penny (op. cit., p. 51) distingue cuatro vocales finales $a, e, u$ abierta y $u$ mixta, y "todas se articulan bastante más relajadas que sus correspondientes castellanas".

104 Precisamente, F. GoNZÁlez Ollé ("Características fonéticas...", cit., p. 71) considera que el cierre de la vocal -o final absoluta de palabra es el rasgo fonético más característico del habla menesa: "mayor o menor, según los hablantes, no es difícil percibirlo y, a veces, se tiene la impresión de escuchar claramente una $-u$.

105 Cf. I. EChevarría Isusquiza, «La aspiración de /f/ inicial latina en Carranza (Vizcaya), según los datos de su microtoponimia", Actas del I I Congreso Internacional de Historia de la Lengua Española (Madrid: Arco, 1992), pp. 247-254. 
como El Hoyo de Joyabuena o El Hoyo de Sandejoyo, en que el tratamiento de la palabra genérica contrasta con el del término fosilizado en el adyacente; también abundan La Joyacha, El Joyacho, La Joyada, El Joyal, El Joyuelo, y compuestos como Joyublanco, Juyojondo, Juyovaleri y otros, alternando a veces con formas $\sin j^{-106}$. En los derivados de FICUS hemos encontrado una sustitución de la velar fricativa sorda por la interdental, caso de La Ciareja / La Higareja / La Jigareja de Soscaño, que se repite en La Ciguera / La Jiguera de Biáñez. De FURCA sobreviven sólo derivados con aspiración conservada, como La Jorca o Las Jorcas, Los Jorcos y el compuesto Cuadrajorco. Presentan cierta complejidad fonética los representantes del latín tardío DEFENSA: La Jesa aparece en el conjunto de topónimos o entre las distintas formas de un mismo topónimo, al lado de La Dehesa / La Desa, La Edesa, La Ejesa, aunque la variante más corriente es la primera. Etcétera. En suma, estos y otros ejemplos presentan discordancia o vacilación con respecto a las formas que el castellano ha fijado, tanto con pérdida del sonido aspirado que representa la sustitución original de la /f-/ latina (jaya, joyo, jorno, etc., por baya, boyo, borno, etc.), como en los casos en que el castellano tiene hoy /f-/ (v. gr., jerrería o jontanía por ferrería o fontanilla). La proyección diacrónica de la variación cristalizada en la toponimia es clara, y proporciona algunos detalles nuevos sobre esa página histórica que es la sustitución de la consonante latina. No cabe duda de que sus ejemplos son el último asilo del arcaísmo castellano norteño, y si la pérdida de la aspiración, aquí como en la comarca al oriente del río Miera (Santander), no ha debido ser muy antigua, hoy todo induce a pensar que la de su desaparición total no está lejana ${ }^{107}$.

No es posible que nos detengamos ahora en la explicación más pormenorizada de rasgos fonéticos de interés que el estudio de topónimos permite y que el estudio del habla, conforme a una metodología dialectológica rigurosa, quizá ocultaría. Pero deseamos indicar, al menos, algunos otros testimonios de fenómenos cuyo interés trasciende lo regional, pues tienen una amplia proyección en la dialectología hispánica:

Por ejemplo, los topónimos carranzanos terminados en -io(s), -ia $(s)$, resultado romance vulgar local del diminutivo -illo, representan una articulación yeísta, al parecer antigua y arraigada (aunque sea sólo en ese

106 Tal alternancia es menos frecuente cuando joyo, en composición, a través de juyo- ha quedado reducido a ju-, como en Julabrena, Julascabras, Julaspozas o Julateja.

107 Cf. L. RODRíguez CASTELlano, "Estado actual de la $b$-aspirada en la provincia de Santander", Archivum, IX (1954), pp. 454-5. 
preciso contexto fonético y morfológico) en la tradición lingüística carranzana y en la Montaña santanderina ${ }^{108}$.

Además, son datos que han de sumarse a los procedentes de otros muchos puntos de la ancha geografía hispánica, aquellos relativos a las alteraciones que afectan a las consonantes implosivas ${ }^{109}$. Varios topónimos documentan el trueque entre - $l$ - y $-r$ - en esta posición: Almayor / Armayor, Marjesa / Maljesa, Bardegalinde / Baldegalindo, Volbuñite / Vurbuñite, El Jalcón / El Jarcón, La Jelguerosa / La Jerguerosa, El Rubial / El Rubiar, El Ser 'sel', etc. R. J. Penny, habiendo observado que el debilitamiento de /-L/ es también característico de algunas hablas montañesas (Tudanca), estima posible que, debido a la naturaleza del fenómeno, éste haya pasado inadvertido en otras hablas septentrionales. Si se probara, podría ser descrito como una innovación norteña suprimida en el centro por una pronunciación burgalesa más conservadora ${ }^{110}$.

Por último, en la relajación de la articulación de las consonantes oclusivas sonoras intervocálicas, que presenta gran intensidad en Carranza, también hemos observado algunos matices diatópicamente diferenciales. No sólo se pierde - $d$ - en la terminación -ado sistemáticamente (otra cosa sería sorprendente), sino también en casos menos generales en el español vulgar peninsular, como se ve en Ejío (-ído), La Cavá y Las Casas Quemás (-áda), Llario (si procede, como proponemos, de Glaretum), Picúo (-údo), y el habla conoce ceazo 'cedazo' (posición interior). En estas condiciones, la pérdida de la consonante es general en andaluz y murciano, pero poco frecuente en otras hablas: no se da en el castellano general y, des-

108 Nos referimos a casos como El Acebio, Las Llamosias, La Bernía, La Callejía, La Campia, Las Casias, Los Castríos, El Cerecio, El Cerrio, La Collaría o La Colladía, El Cuadrío, La Cubia, etc. De ellos tratamos en "Una contribución...", cit., trabajo al que remitimos.

109 Cf. T. NAVARro TOMÁs, op. cit., \$\$111-115; A. AlONSO, " $r$ y $-l$ en España y América", Estudios lingüísticos. Temas bispanoamericanos (Madrid: Gredos, 1961), pp. 217 y ss.

110 Cf. R. J. PENNY, "The Peninsular expansion of Castilian", Bulletin of Hispanic Studies, LX (1983), p. 334. Además, hay en Carranza algunos casos de -r implosiva por -s: Mier / Mies, Bortezuelo / Bostezuelo, Burgüeno / Busgüeno, La Costeriza / La Corteriza. Las hablas montañesas conocen mier por mies (A. GaRcía Lomas, op. cit., p. 46); R. J. Penny advierte que, en el habla pasiega, la /s/ final de sílaba ante consonante sonora se realiza como $r$ fricativa: mar de dos, el mer de eneru, er güenu, etc. (El habla pasiega..., cit., pp. 56-57). Pero no es un rasgo sólo montañés, pues el debilitamiento de $/ \mathrm{s} / \mathrm{y} / \Theta /$ finales de sílaba, que se manifiesta en la realización de $s$ como $r$ fricativa bastante regularmente tras $d$, muestra creciente intensidad a lo largo de la historia del español; cf. R. J. PENNY, Gramática bistórica del español (Barcelona: Ariel, 1993), pp. 104-105. 
de luego, está ausente del de Vizcaya, excepto, como vemos, en Las Encartaciones, cuyo romance conecta de nuevo con lo montañés y el área asturiano-leonesa ${ }^{111}$. También abundan en la toponimia de Carranza los casos de pérdida de -g-(procedente de -C- y de -G- latina): La Ciareja / La Higareja o La Jigareja, Los Jilieros y El Jeliero (de FILICARIU), El Launal 'lagunal', El Llao 'lago' y Los Llaos ${ }^{112}$, El Miajón, La Reada / La Reata (junto a La Regada / La Arregada / La Rigada), El Reanillo / El Reganillo, Los Sabúos 'saúcos', Tasueras 'tasugueras', y otros ${ }^{113}$. La pérdida de la articulación de /-b-/ ocurre en Araúste / Arabuste, Arrieras (variante de riberas), La Sabuguilla / La Sauguilla, Los Cáraos 'cárabos' o El Poedal, variante de pobedal. También en este caso sólo volvemos a hallar grupos de ejemplos significativos en las áreas asturiana y andaluza ${ }^{114}$.

El que el español de Vizcaya desconozca completamente estas tendencias fonéticas, mientras que Las Encartaciones las han acogido y ofrecen datos para su estudio, puede constituir una prueba de la distinta cronología de ambos romances.

111 Ejemplos andaluces y murcianos en A. ZAMORA VICENTE, Dialectología española (Madrid: Gredos, 1969) (2. a ed. muy aumentada), pp. 316-7 y 341; A. GARCíA LOMAS (op. cit., p. LV) recoge formas como sentíu; merecía, des- > es-y otros casos de pérdida en posición inicial e interior (ondi, meodia, réitos); también son montañeses deo, peazo, tovía, colgaíza, oíu, templá, jondalá, zurriscá (V. RENERO, op. cit., pp. 140 y 142); F. GARCía GonzÁlez (op. cit., pp. 475-6) selecciona algunos de los que aparecen en la novela Peñas arriba (coyá, aentru, peazus, etc.). Los bables muestran una característica tendencia a la eliminación de las sonoras procedentes de las sordas latinas: algunos ejemplos asturianos de pérdida de $-d-(<-\mathrm{T}-)$ recopilados por ZAMORA VICENTE (op. cit., p. 158) son mieu 'miedo' y rendiu.

112 En un documento del AHPV (1852) figura un vecino llamado José Llaguno, apellido que después, en el mismo texto, aparece escrito Llauno.

113 La omisión de /g/ intervocálica en español está mucho más restringida que la de la $/ \mathrm{d} /$, aunque sea típica en aüja o aujero (R. LAPESA, op. cit., pp. 467-8; T. NAVARRO TOMÁs, op. cit., \$127). Otros ejemplos son el montañés maíllo 'maguillo' (V. RENERO, op. cit., p. 140); en Treviño, reajo, riajo 'regajo', Launa y otros (M. N. SÁNCHEZ GONZÁlEZ DE HERRERO, op. cit., p. 32); en el bable occidental los testimonios son algo más abundantes: El Puntíu, fuéu, lluéu, etc.; cf. C. C. García VAldÉs, "El habla de Santianes de Pravia", Boletín del Instituto de Estudios Asturianos, XCIII-XCIV (1978), p. 158; para la pérdida de $-g-\left(<-\mathrm{K}_{-}\right)$en leonés cf. A. ZAMORA ViCENTE, op. cit., p. 158.

114 Son ejemplos asturianos fáula < FABULA, sacaéra (asturiano general sacabera); arria < AD RIPA, oeyas 'ovejas', oeyeros 'pastores de ovejas', cleu 'clavo', co < CAPUT, 'junto a', etc.; anuláo 'nublado' y toíllo 'tobillo' son andaluces (A. ZAMORA VICENTE, op. cit., pp. 158 y 317). 
ISABEL ECHEVARRÍA ISUSQUIZA

\section{OBSERVACIONES FINALES}

Este escueto compendio presenta los trazos principales del perfil histórico del habla de una comarca castellana mal conocida. Aunque uno de los puntos encuestados para el $A L P I$ fue Beci (el n. ${ }^{\circ} 428$ ), en Sopuerta, su cuestionario no permitió registrar la fina subdiferenciación castellana que corresponde a Las Encartaciones o al norte de Burgos, ni distinguir si el castellano de la zona es reciente $\mathrm{o}$ antiguo ${ }^{115}$. Esto explica que encontremos afirmaciones como la de $\mathrm{H}$. Guiter cuando señala que "l'ouest de la Vizcaya et la majeure partie de l'Alava sont castellanisés" ${ }^{116}$; sin embargo, si ningún lingüista afirmaría que el valle de Mena (norte de Burgos) ha sido castellanizado (porque simplemente es castellano, peculiarmente norteño), creo que puede reclamarse idéntica consideración para el occidente de Vizcaya. Merece destacarse que el ALECan $^{117}$ incluye entre los puntos encuestados un lugar de Las Encartaciones: Villaverde de Trucíos (S 401), villa cántabra enclavada en nuestra comarca y vecina a Carranza. Sus datos muestran, con veracidad y en la perspectiva de conjunto que el atlas proporciona, el estado actual de nuestra habla en relación con el área montañesa. Sin embargo, hoy que la extensión del español general hace a las hablas castellanas tan iguales en todas partes, el análisis sincrónico contemporáneo vela aspectos históricos y dialectales que sólo una prospección cronológica como la que posibilita un estudio toponímico permite conocer. Desde este ángulo, el romance de Las Encartaciones constituye una pieza bien diferenciada en el romance vizcaíno.

Los particularismos del Lexicón de Arriaga, que refleja aspectos del vocabulario de Bilbao a fines del siglo XIX (1896), resultan ajenos al occidente vizcaíno, en la medida en que estos bilbainismos son, sobre todo, vasquismos: amaiquetaco 'tentempié', arringorri 'cierto pez', arribolas 'piedras de empedrado', biocherre 'dispepsia', colco 'seno', chita 'polluelo', chori 'coleta', choriburu 'persona de poca cabeza', churrutada 'trago', larri 'triste', lochabaco 'sinvergüenza, etc. ${ }^{118}$. Estas y otras voces típicas del castellano

115 T. NAVARro TOMÁs (dir.) y R. BALBÍn (coord.), Atlas Lingüístico de la Península Ibérica, vol. I, Fonética (Madrid: CSIC, 1962).

116 H. GuITER, "Étalonnage d'une méthode géolinguistique", Revue de Linguistique Romane, LI (1987), p. 55, n. 2.

117 M. AlVAr LóPEZ (dir.), Atlas lingüístico y etnográfico de Cantabria (Madrid: Arco, 1995) (2 vols.).

118 Además del Lexicón de Arriaga, disponemos del viejo texto de P. DE MúGiCA, Dialectos castellanos. Montañés, vizcaino, aragonés (Berlín: Kemke, 1892), cuyo "dialecto vizcaíno" parece el mismo "bilbaíno" de Arriaga; una investigación más reciente 
tradicional de Bilbao no se registran en Las Encartaciones, y, recíprocamente, los particularismos del léxico de esta comarca no aparecen en el habla bilbaína, en general. Dicho de otro modo, las voces cueto 'pequeña colina cónica' y ondaquín 'residuo' corresponden a dos hablantes vizcaínos distintos, a dos áreas diferentes, separadas históricamente por el Nervión ${ }^{119}$.

La referencia distintiva a Las Encartaciones falta allí donde sería necesaria para una cabal comprensión de los hechos que desea explicar la lingüistica hispánica de perspectiva espacio-temporal: por ejemplo, en su indagación sobre la fecha del yeísmo, Corominas apuntaba: «...quizá lleta sea palabra navarro-aragonesa, pues aparece por primera vez en el vasco Terreros (hacia 1764), si bien no la creo autóctona de esta región..." "20. Desde luego, si el argumento es la comunidad de influencias vascas en "el vasco Terreros" y el navarro-aragonés, la confusión es muy elocuente: no todo lo vizcaíno es vasco y, precisamente, el romance de Las Encartaciones, de donde era natural Esteban Terreros (Trucíos), está, como ha podido entreverse, mucho más cerca del astur-leonés que del navarro-aragonés.

Las Encartaciones deben analizarse como parte del complejo castellano en su solar primitivo, lo que quizá no pueda afirmarse, sin añadir varios matices, del romance vizcaíno, aunque, según Gregorio Salvador, el romance vasco medieval cuya existencia ha supuesto Echenique, verosímilmente "Sería castellano como el de Las Encartaciones o las tierras de Álava" ${ }^{21 .}$

ISABEL ECHEVARRÍA ISUSQUIZA

Universidad del País Vasco. Vitoria

es la de M. EtXebarria Arostegi, El habla de Bilbao. Sociolingüistica urbana (Salamanca: Universidad de Salamanca, 1985), que se centra en los usos léxicos actuales, en los que pretende descubrir la influencia de ciertas variables como "origen de los informantes", "hablantes o no de euskera", "zona", "sexo" y otras.

119 Insistimos ahora en la diferencia, porque siendo tan relevante no ha merecido ninguna atención. Sin embargo, no es menos cierto que en la propia comarca de Las Encartaciones, podría distinguirse una zona occidental, más arcaizante y dialectal, y un área oriental, más meridional y castellana, que se encuentra en el camino de Burgos (capital) a Bilbao. Hay razones históricas que permiten conjeturar que si Las Encartaciones se encuentran en una de las rutas de la Meseta a Bilbao, también su romance puede haber sido uno de los veneros del bilbaíno, el cual, a su vez, ha debido ejercer una enorme influencia en la castellanización de su entorno.

120 J. Corominas, "Para la fecha del yeísmo y del lleísmo", Nueva Revista de Filología Hispánica, VII (1953), p. 85.

121 G. Salvador ha señalado reiteradamente este hecho que parece una evidencia histórica: si la pérdida más temprana de toda huella de $f$ - latina, documentada bajo la 
El propósito de estas páginas es caracterizar algunos aspectos lingüísticos, léxicos y también fonéticos, del habla de una región castellana desconocida para la dialectología española: el occidente vizcaíno. Nuestra fuente y fundamento son los testimonios que la toponimia proporciona. Tal vez sólo la toponimia ofrece datos relevantes acerca de los dos temas históricos de interés que afectan a la zona: su ubicación con respecto al límite noroccidental de la lengua vasca, y el perfil del romance, castellano, que hoy se habla en ella. Hemos hallado continuidad de tipos léxicos y rasgos fonéticos en un área iberorromance occidental amplia, y otra, más restringida, castellana norteña; ésta suele comprender, con el norte de Burgos, Álava y La Rioja, pero la afinidad más constante y manifiesta se da con las hablas montañesas.

The main purpose of this paper is to characterize some linguistic aspects -lexical as well as fonetic - of the Castilian speech of the little known region of western Vizcaya. Our source and the foundation of our observations are minor placenames. Only Toponymy is able to provide the interesting and relevant data on two aspects concerning this region that are historically significant: its location with respect to the northwestern boundary of the Basque language area and the profile and features of the Castilian spoken there today. Place-names provide information with which we can sketch speech traditions in the region and increase our knowledge of both northern Castilian and the history of the romance language spoken in Vizcaya.

forma del hagiotopónimo Santelices, sólo la encontramos en el norte de Burgos y en las Encartaciones de Vizcaya, "quiere esto decir que lo mismo las Encartaciones de Vizcaya que la Álava latinizada fueron parte del solar del primitivo castellanon; cf. G. SALVADOR, Juntos y revueltos: la larga convivencia del vascuence y el castellano (Bilbao: Sociedad "El Sitio", 1989), pp. 5 y 11. 